Marquette University

e-Publications@Marquette

Chemistry Faculty Research and Publications

Chemistry, Department of

4-1-2006

\title{
Thermal Degradation of Acetate-Intercalated Hydroxy Double and Layered Hydroxy Salts
}

Everson Kandare

Jeanne Hossenlopp

Marquette University, jeanne.hossenlopp@marquette.edu

Accepted version. Inorganic Chemistry, Vol. 45, No. 9 (April 2006): 3766-3773. DOI. (C) 2006

American Chemical Society. Used with permission. 


\title{
Thermal Degradation of Acetate- Intercalated Hydroxy Double and Layered Hydroxy Salts
}

\author{
Everson Kandare \\ Department of Chemistry, Marquette University, \\ Milwaukee, WI \\ Jeanne M. Hossenlopp \\ Department of Chemistry, Marquette University, \\ Milwaukee, WI
}

Synopsis: The gas-phase products from thermal degradation of zinccontaining layered metal hydroxides with intercalated acetate anions depend on the identity of metals in the hydroxide layers. Zinc hydroxy acetate and zinc/nickel hydroxy acetate precursors promote ketonization to produce acetone while this channel is suppressed in zinc copper hydroxy acetate. Growth of ZnO crystallites is also precursor dependent. 


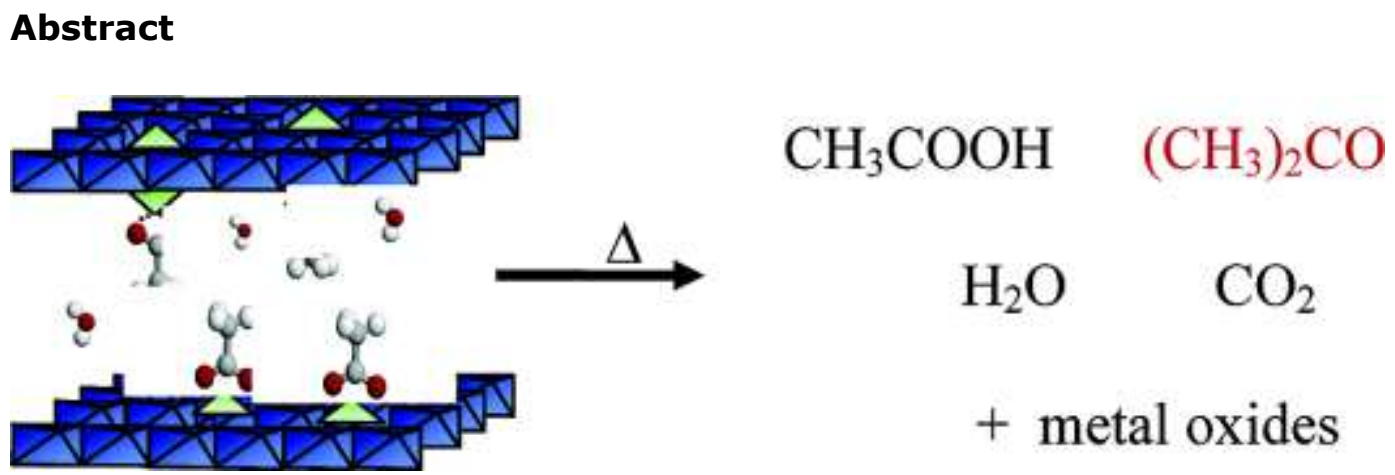

Two hydroxy double salts (HDSs), zinc copper hydroxy acetate (ZCA) and zinc nickel hydroxy acetate (ZNA), and an analogous layered compound, zinc hydroxy acetate ( $\mathrm{ZHA})$, have been prepared by a coprecipitation method. The thermal degradation of these materials was characterized via thermogravimetric analysis (TGA), differential thermal analysis (DTA), and TGA coupled with Fourier transform infrared spectroscopy of gas-phase products, TGA-FTIR. Loss of physisorbed and interlayer $\mathrm{H}_{2} \mathrm{O}$ was observed between 50 and $150{ }^{\circ} \mathrm{C}$ for all compounds. Acetic acid, acetone, water, and $\mathrm{CO}_{2}$ were released at high temperatures with relative acetone yields found to be dependent on precursor identity, with very little formed from ZCA compared with ZHA and ZNA. Combined FTIR and XRD analysis of solid residues extracted at different points in the heating profile suggests that ketonization occurs via dissociative adsorption of acetic acid on $\mathrm{ZnO}$ surfaces. Nanometer-sized ZnO particles were formed from ZHA, showing slight preferential growth in the $\mathrm{ZnO}(002)$ lattice direction, while the presence of a second metal, $\mathrm{Ni}$ or $\mathrm{Cu}$, served to retard $\mathrm{ZnO}$ crystallite growth at temperatures below $600{ }^{\circ} \mathrm{C}$ and eliminate preferential growth. ZCA leads to the formation of reduced copper species (metallic copper and $\mathrm{Cu}_{2} \mathrm{O}$ ) when heated to $250{ }^{\circ} \mathrm{C}$.

\section{Introduction}

Layered metal hydroxides with exchangeable interlayer anions can be utilized to provide nanodimensional structures with tunable physical and chemical properties..$^{1-9}$ Examples of these materials include layered double hydroxides ( $\mathrm{LDHs})\left[\mathrm{M}^{2+}{ }_{x} \mathrm{M}^{3+}{ }_{1-x}(\mathrm{OH})_{2}\right]^{x+}\left(\mathrm{A}^{n-}\right.$ $x / n) \cdot m \mathrm{H}_{2} \mathrm{O}$, hydroxy double salts (HDSs) $\left[\left(\mathrm{M}^{2+}{ }_{1-x} \mathrm{M}^{2+}{ }_{1+x}\right)(\mathrm{OH})_{3(1-y) / n}\right] \mathrm{A}^{n-}$ $(1+3 y) / n \cdot \mathrm{mH}_{2} \mathrm{O}$ where $\mathrm{M}^{2+}$ and $\mathrm{M}^{2+}$ represent the different divalent metals, and the analogous layered hydroxy salts (LHSs) containing a single metal. The ability to vary the intralayer metal composition, as well as the interlayer anion identity, makes these materials attractive for a broad range of applications including use as catalysts, ${ }^{1,2}$ catalyst precursors, ${ }^{3-5}$ catalyst support material, ${ }^{6}$ adsorbents, antacids, ${ }^{7}$ and ion exchangers. ${ }^{8,9}$ 
These materials are also of interest as possible fire retardant additives for polymers. Previous work in our laboratory has shown that the addition of copper-containing HDSs or LHSs to poly(methyl methacrylate $)^{10,11}$ or poly(vinyl ester) $\underline{12,13}$ results in enhanced thermal stability. Significant reductions were observed in total heat release, as measured via cone calorimetry, and there was an increase in the amount of char formed compared with the virgin polymer. Reduced copper species ( $\mathrm{Cu}$ and/or $\mathrm{Cu}_{2} \mathrm{O}$ ), which may play a catalytic role in the stabilization process, were observed in the pyrolysis residues. Detailed characterization of the thermal degradation pathways of HDSs and LHSs in the absence of polymers is necessary to fully understand the role that these materials play in protecting polymer composites.

Most literature reports to date have focused on thermal degradation of LDHs to yield a mixture of metal oxides. $\frac{14-21}{}$ Formation of metal oxides for catalysis has been achieved through thermal decomposition of metal salts or crystalline hydrated organic salts. $\underline{22-25}$ Both dynamic and static thermal processes are useful for the preparation of metal oxides for basic research and technological applications. For instance, ZnO nanoparticles have been shown to exhibit unique physical and chemical properties with a wide range of applications as in cosmetics, surface acoustic wave device filters, photodetectors, and gas sensors. $\frac{26}{}$ Layered materials with predetermined metal ratios serve well as precursors for well-dispersed oxides that can be used as homogeneous multicomponent catalysts. Variations in the conditions employed in solvothermal processes ${ }^{27-29}$ have been used to prepare nanocrystals of varying shapes and sizes.

In this work, a detailed analysis of the thermal degradation pathways is obtained for a set of acetate-containing HDS and LHS model compounds in order to explore the role of intralayer metal composition.

\section{Experimental Section}

Zinc hydroxy acetate (ZHA), zinc copper acetate (ZCA), and zinc nickel acetate (ZNA) HDSs were prepared using a literature synthesis. $\frac{30}{}$ Copper acetate monohydrate, (98.0\%) $\left[\mathrm{Cu}\left(\mathrm{CH}_{3} \mathrm{COO}\right)_{2} \cdot \mathrm{H}_{2} \mathrm{O}\right]$, zinc acetate $(99.9 \%)\left[\mathrm{Zn}\left(\mathrm{CH}_{3} \mathrm{COO}\right)_{2}\right]$, nickel 
acetate tetrahydrate, $(98.0 \%)\left[\mathrm{Ni}\left(\mathrm{CH}_{3} \mathrm{COO}\right)_{2} \cdot 4 \mathrm{H}_{2} \mathrm{O}\right]$, and zinc oxide $(99.9 \%)$ [ $\mathrm{ZnO}$ ] were used as obtained from Aldrich Chemical Co. ZHA was made from mixing $0.41 \mathrm{~g}$ of $\mathrm{ZnO}(5 \mathrm{mmol})$ with $0.92 \mathrm{~g}(5 \mathrm{mmol})$ of $\mathrm{Zn}\left(\mathrm{CH}_{3} \mathrm{COO}\right)_{2}$ in $10 \mathrm{~mL}$ of water with vigorous stirring at room temperature. The resultant suspension was allowed to stand for $24 \mathrm{~h}$. The precipitate was recovered by filtration, washed repeatedly with water, and dried at room temperature. ZNA and ZCA were prepared in the same way from $5 \mathrm{mmol}$ equivalents of $\mathrm{ZnO}$ and the corresponding metal acetates in $10 \mathrm{~mL}$ of water.

XRD patterns were obtained by a Rikagu powder diffractometer operating in parafocusing Bragg-Bretano configuration, with a $1 / 2^{\circ}$ divergence slit (DS), $1 / 2^{\circ}$ scatter slit (SS), $0.15 \mathrm{~mm}$ receiving slit (RS), and $0.15 \mathrm{~mm}$ monochromator receiving slit (MRS) using $\mathrm{Cu} \mathrm{Ka}$ $(\lambda=1.54 \AA)$ radiation source operated at $1 \mathrm{~kW}$. Data acquisition was performed using $0.036^{\circ}$ steps, integrating $20 \mathrm{~s} /$ step. Powder samples were mounted on quartz slides using 10\% GE 7031 epoxy in ethanol after confirming that the epoxy did not perturb the observed XRD patterns. Peak positions were determined by fitting XRD data to a pseudo-Voight function using XFIT, $\underline{31}$ stripping off the $\mathrm{Cu} \mathrm{Ka}_{2}$ wavelength contributions. Basal spacings characterizing these layered compounds were obtained using Bragg equation, $\lambda=2 \mathrm{~d} \sin \theta$, averaging $00 /(I=1-3)$. Average crystallite sizes, $\mathrm{T}$, were determined using the Debye-Scherrer equation:

$$
\tau=\kappa \lambda /\left(\beta_{\mathrm{z}} \cos \theta\right)
$$

where $\mathrm{k}$ is a constant ( 0.9 for powders), $\underline{32} \beta_{\mathrm{T}}$ is the full width at halfmaximum height of the target diffraction peak of the material after correction for $\mathrm{Cu} \mathrm{Ka}$ and the instrumental broadening, and $\lambda$ is the $X-$ ray wavelength, $1.54 \AA$ for $\mathrm{Cu} \mathrm{Ka}$. Assignments of known compounds were made using the powder diffraction file (PDF). $\underline{33}$

Fourier transform infrared (FTIR) spectra of the solid materials were obtained using the $\mathrm{KBr}$ method on a Nicolet Magna-IR 560 spectrometer in the $400-4000 \mathrm{~cm}^{-1}$ region with the spectra collected at $1 \mathrm{~cm}^{-1}$ resolution, averaging 40 scans. Calcined inorganic residues were stored in a desiccator prior to making FTIR measurements. Thermogravimetric analysis (TGA) was performed to determine 
thermal stability and degradation pathways using a Cahn TG-131 device in the temperature range of $50-600{ }^{\circ} \mathrm{C}$ at a heating rate of $20^{\circ} \mathrm{C} / \mathrm{min}$ in air, flowing at $85 \pm 5 \mathrm{~mL} / \mathrm{min}$, with sample sizes of 55.0 $\pm 5.0 \mathrm{mg}$ contained in quartz cups. The gaseous products of the decomposition process were analyzed using a Mattson-FTIR interfaced with the Cahn TG-131 device. Differential thermal analysis (DTA) was performed on a SDT 2960 simultaneous DTA-TGA instrument from 50 to $600{ }^{\circ} \mathrm{C}$ using $20 \pm 1 \mathrm{mg}$ samples heated between 50 and $600^{\circ} \mathrm{C}$ at $20^{\circ} \mathrm{C} / \mathrm{min}$ with air as the purge gas (flow rate, $85 \pm 5 \mathrm{~mL} / \mathrm{min}$ ).

The identities of the combustion gases were determined by comparing their FTIR spectra to NIST standards. $\frac{34}{\text { Diffuse reflectance }}$ spectra (DRS) of the samples were taken on a Shimadzu UV-2501PC in the reflectance mode at room temperature using $\mathrm{BaSO}_{4}$ as a reference, with the arbitrary absorbance spectra recalculated using the Kubelka-Munk (KM) equation, defined as follows

$$
F\left(R_{s}\right)=(1-R)^{2} / 2 R
$$

where $F\left(R_{\infty}\right)$ is analogous to absorbance and $R$ is the reflectance percent fraction. Elemental analysis was carried out by Huffman Labs, Colorado, using the atomic emission spectroscopy interfaced with inductively coupled plasma (AES-ICP) for metals determination. ZCA: $\mathrm{Cu}_{3.6} \mathrm{Zn}_{1.4}(\mathrm{OH})_{7.6}\left(\mathrm{CH}_{3} \mathrm{CO}_{2}\right)_{2.4} \cdot 5 \mathrm{H}_{2} \mathrm{O}$, [Cu (33.6\% calcd, 35.6\% exptl), $\mathrm{Zn}$ (13.4\% calcd, $14.8 \%$ exptl), C (8.5\% calcd, 9.4\% exptl), H (3.7\% calcd, 3.2\% exptl)], ZHA: $\mathrm{Zn}_{5}(\mathrm{OH})_{8}\left(\mathrm{CH}_{3} \mathrm{CO}_{2}\right)_{2} \cdot 4 \mathrm{H}_{2} \mathrm{O}$, [ $\mathrm{Zn}(50.1 \%$ calcd, $48.8 \%$ expt) $) \mathrm{C}(7.4 \%$ calcd, $7.6 \%$ exptl), $\mathrm{H}$ (3.4\% calcd, $3.25 \%$ exptl)] and ZNA: $\mathrm{Zn}_{3.2} \mathrm{Ni}_{1.5}(\mathrm{OH})_{7.9}\left(\mathrm{CH}_{3} \mathrm{CO}_{2}\right)_{1.5} \cdot 1.7 \mathrm{H}_{2} \mathrm{O}[\mathrm{Zn}$ (38.0\% calcd, $35.7 \%$ exptl), Ni (16.0\% calcd, $14.9 \%$ exptl), C $(6.5 \%$ calcd, $7.6 \%$ exptl), H (2.9\% calcd, 3.25\% exptl)].

\section{Results and Discussion}

ZHA and ZNA are expected to have structures consistent with brucite-like 35,36 layered compounds where the second metal occupies tetrahedral sites above and below vacant octahedral positions. Anions bind to the tetrahedral sites. ZCA has been hypothesized to have a botallackite-like structure, $\mathrm{Cu}_{2}(\mathrm{OH}){ }_{3} \mathrm{Cl}$, (PDF no. 8-88) ) $^{33}$ as extensively

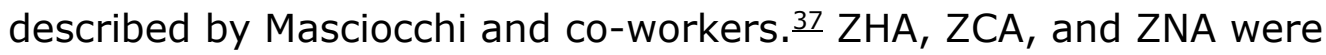


synthesized as described above, and some of the key structural parameters are summarized below. Additional discussion can be found in our previous study of anion-exchange kinetics in these model systems. $\underline{38}$

Basal spacings were found ${ }^{38}$ to agree well with literature values. The spacing for ZCA was found to be $9.3 \AA$, comparable to the literature value of $9.4 \AA .{ }^{30}$ Larger basal spacings of 13.6 and $13.0 \AA$ similar to 13.2 and $12.8 \AA^{30}$ were observed for ZHA and ZNA, respectively. The crystallite size in the $c$-axis direction was calculated to be $540 \pm 30 \AA$ for $Z C A, 270 \pm 40 \AA$ for $Z N A$, and $350 \pm 45 \AA$ for ZHA.

The TGA and corresponding derivatized mass, DTG, curves of ZHA heated in air from 50 to $600^{\circ} \mathrm{C}$ are shown in Figure $1 \mathrm{~A}$, and the DTA curve for the corresponding heating ramp is shown in Figure $1 \mathrm{~B}$. The TGA and DTG curves exhibit two distinct degradation regions: one in the temperature range of $50-150{ }^{\circ} \mathrm{C}$ and the other in the range of $150-350{ }^{\circ} \mathrm{C}$. A final total mass loss of $38 \%$ is observed. This compares well with the expected mass loss of $37 \%$, which is based on formation of $\mathrm{ZnO}$ as the final product from the empirical formula of the ZHA precursor. Combining the TGA and DTA data with TGA-FTIR experiments provides a detailed view of the decomposition process. FTIR spectra of the gas-phase products from thermal decomposition of ZHA in air are presented in Figure 2.

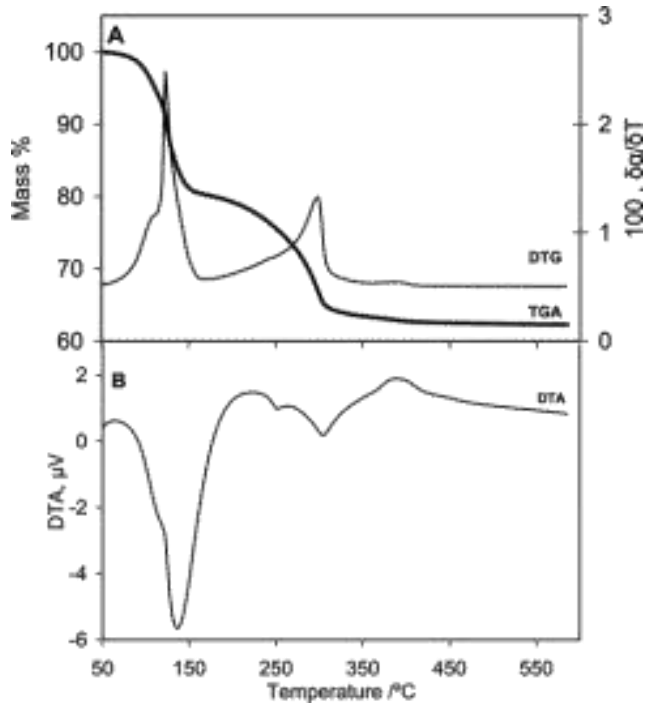

Figure 1 (A) TGA and corresponding DTG curves of ZHA from 50 to $600{ }^{\circ} \mathrm{C}$ at $20^{\circ} \mathrm{C} / \mathrm{min}$ in air. (B) DTA curve for ZHA from 50 to $600^{\circ} \mathrm{C}$ at $20^{\circ} \mathrm{C} / \mathrm{min}$ in air.

Inorganic Chemistry, Vol 45, No. 9 (April 2006): pg. 3766-3773. DOI. This article is (C) American Chemical Society and permission has been granted for this version to appear in e-Publications@Marquette. American Chemical Society does not grant permission for this article to be further copied/distributed or hosted elsewhere without the express permission from American Chemical Society. 
NOT THE PUBLISHED VERSION; this is the author's final, peer-reviewed manuscript. The published version may be accessed by following the link in the citation at the bottom of the page.

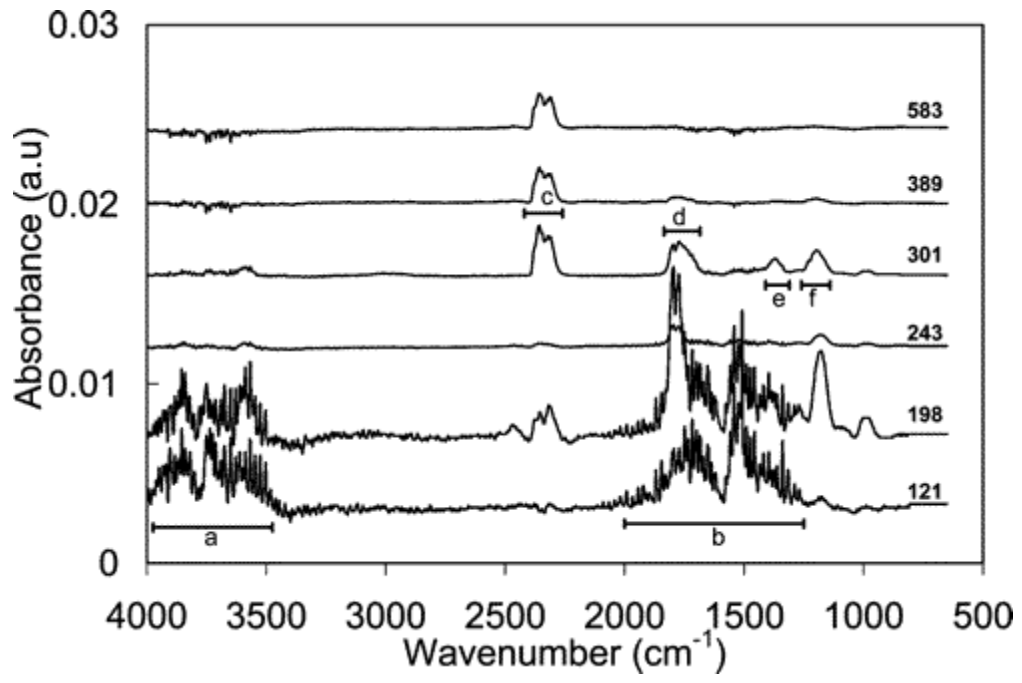

Figure 2 FTIR spectra of evolved gaseous products collected at the temperature $\left({ }^{\circ} \mathrm{C}\right)$ indicated on the right of each spectrum during thermal combustion of ZHA in air $\left(20^{\circ} \mathrm{C} / \mathrm{min}\right)$. FTIR spectra were scaled by dividing by 10 except for those at 121 and $198^{\circ} \mathrm{C}$, which were not scaled. Expected positions of absorption bands for water stretching modes (a), bending mode (b), $\mathrm{CO}_{2}$ antisymmetric stretch (c), overlapping acetic acid and acetone $\mathrm{C}=\mathrm{O}$ stretch (d), $\mathrm{CH}_{3}$ deformation (e), and $\mathrm{C}-\mathrm{C}$ bending for acetone and $\mathrm{C}-\mathrm{O}$ stretch for acetic acid (f) are shown. See Figure 3 for further detail on acetic acid and acetone spectra.

Surface-adsorbed and intercrystalline water molecules are lost in the first degradation stage. A shoulder at about $110^{\circ} \mathrm{C}$ in the DTA curve, shown in Figure $1 B$, is assigned primarily to the loss of the external surface water molecules, while a stronger endothermic feature centered at $140{ }^{\circ} \mathrm{C}$ is attributed to the loss of the intergallery hydrogen-bonded water molecules. The FTIR spectrum at $121^{\circ} \mathrm{C}$ confirms the departure of water is the primary channel during the first degradation step. The expected weight loss due to simple dehydration, based on having four water molecules per formula unit, is $11 \%$. However, the weight loss in the first stage is significantly higher, approximately $18 \%$. This suggests that there may be partial dehydroxylation in this low-temperature regime. The second degradation stage is attributed to the collapse of the intralayer structure releasing a variety of products. Stable products may include acetic acid produced via deanation; acetone generated via ketonization of acetic acid; water which may be generated via dehydroxylation of $\mathrm{Zn}-\mathrm{OH}$ linkages, thermo-oxidation of organic species, and ketonization of acetic acid; and carbon dioxide resulting from thermo-oxidation of organic species and ketonization of acetic acid. The evolution of 
$\mathrm{CH}_{3} \mathrm{CO}_{2} \mathrm{H}$ begins at about $150{ }^{\circ} \mathrm{C}$ and peaks at around $305^{\circ} \mathrm{C}$, suggesting that the second stage of decomposition is mainly due to the loss of the acetate groups. In addition to formation of acetic acid, acetone, water, and $\mathrm{CO}_{2}$ are formed at temperatures above $300{ }^{\circ} \mathrm{C}$. The FTIR spectrum of gaseous products evolved at $328{ }^{\circ} \mathrm{C}$ along with reference spectra ${ }^{34}$ of acetic acid and acetone are shown in Figure 3; additional spectra obtained between 300 and $400{ }^{\circ} \mathrm{C}$ are found in the Supporting Information.

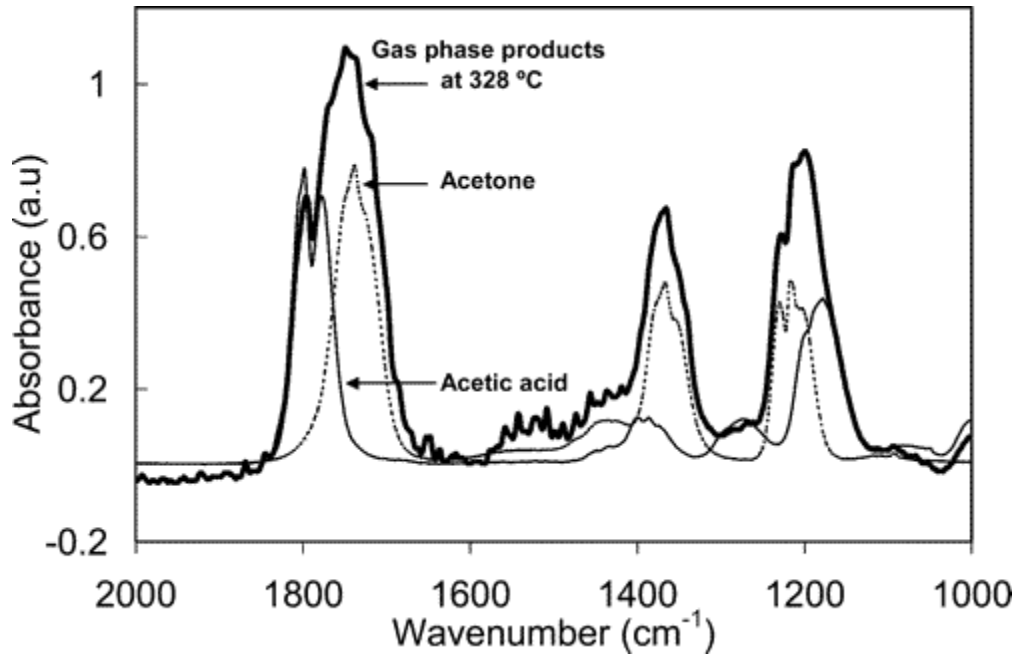

Figure 3 FTIR spectra of evolved gaseous products collected at $328^{\circ} \mathrm{C}$ during thermal combustion of ZHA in air, acetic acid, and acetone. Literature ${ }^{34}$ acetic acid and acetone spectra were scaled to fit on the same plot.

Aliphatic carboxylic acids having a-hydrogens undergo bimolecular decarboxylative coupling (ketonization) yielding ketones. 39,40 Two mechanisms for the formation of acetone from acetic acid over metal oxide catalysts have been proposed. In the first mechanism, proposed for oxides of low lattice energy, bulk acetates are formed first and then subsequently decompose pyrolytically into acetone and $\mathrm{CO}_{2} \cdot \frac{41-43}{3}$ This is promoted by strong basicity (ionicity) of these oxides. In the second mechanism, for oxides of high lattice energy, the initial step of ketonization involves adsorptive interaction of acetic acid molecules with the metal oxide surface generating surface acetate species. Abstraction of an a-hydrogen atom from the acetate anion oriented parallel to the surface of the catalyst leads to the formation of an alkylidene group which in turn reacts with a neighboring carboxylate and hydrogen to form acetone, water, and $\mathrm{CO}_{2} \cdot{ }^{39,40}$ To evaluate these potential mechanisms, solid residues were 
extracted at different points along the heating ramp and analyzed via XRD and FTIR spectroscopy.

XRD patterns of the inorganic residue collected after heating $\mathrm{ZHA}$ in air at a ramp rate of $20^{\circ} \mathrm{C} / \mathrm{min}$ up to the indicated temperatures are shown in Figure 4 . Calcination to $150^{\circ} \mathrm{C}$ yields a mixture of ZHA and wurtzite ZnO (P 6(3) mc; PDF no. 36-1451) 33 $^{33}$ marked with open diamonds. The observation of $\mathrm{ZnO}$ reflections after heating to this temperature is consistent with the previously noted extent of water loss beyond that which is expected from the number of water molecules per precursor formula unit. Some dehydroxylation of ZHA to form ZnO and water may be occurring in this low-temperature regime. However, the existence of $(00 /)$ reflections of $Z H A$ to the third order at temperatures as high as $250^{\circ} \mathrm{C}$ implies that much of the ZHA phase is thermally stable throughout the first stage of mass loss. Surprisingly, the interlayer spacing increased by $1.7 \AA$ with temperature, probably a result of the rearrangement of the acetate anions in the gallery space following the loss of intercrystalline water molecules.

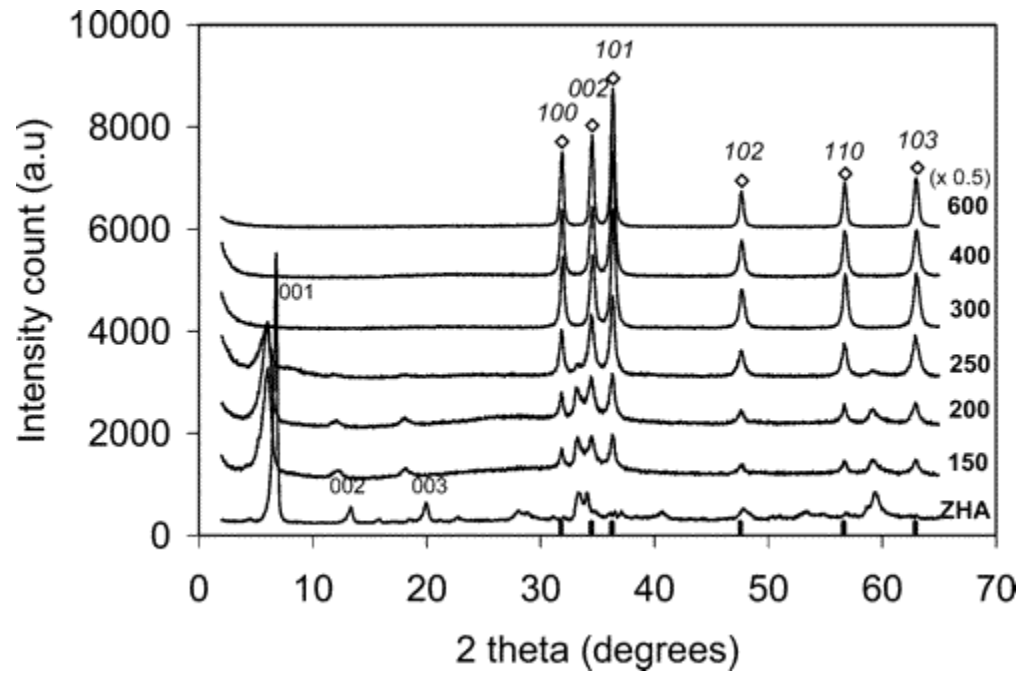

Figure $4 \mathrm{XRD}$ analysis of residual products collected at various times during thermal combustion of ZHA in air $\left(50-600^{\circ} \mathrm{C}\right)$. Samples were heated at $20^{\circ} \mathrm{C} / \mathrm{min}$ to the final temperature shown on the right. $\mathrm{ZnO}$ expected peak positions are shown with sticks on the bottom of the figure; Miller indices are labeled on the top.

Calcination of ZHA at higher temperatures leads to formation of polycrystalline $\mathrm{ZnO}$; peak positions and relative intensities for the sample heated to $600{ }^{\circ} \mathrm{C}$ are found in Table 1 . Heating between 300 and $600{ }^{\circ} \mathrm{C}$ yields wurtzite $\mathrm{ZnO}$ as the only polycrystalline phase. 
Average ZnO crystallite sizes, as determined from the width of the (100) reflection, are listed in Table 2 . The crystallite size increases with temperature from $322 \pm 22 \AA$ after annealing to $250{ }^{\circ} \mathrm{C}$ to 585 $\pm 56 \AA$ upon heating to $600^{\circ} \mathrm{C}$. Relative intensities of the $\mathrm{ZnO}$ reflections exhibit a slight propensity for growth in the (002) lattice dimension. The (002) peak is more intense than the (100) peak, a reversal of what is expected for polycrystalline $\mathrm{ZnO} .{ }^{33}$ Morioka and coworkers reported a more pronounced preference for crystalline growth along the (002) lattice direction when annealing ZHA at $600{ }^{\circ} \mathrm{C}$ for 60 min; their data are also summarized in Table $1 .{ }^{30} \mathrm{ZnO}$ microstructure derived from ZHA is thus sensitive to the thermal degradation protocol employed.

Table 1. ZHA Thermal Residue: Relative Intensities of ZnO X-ray Diffraction Peaks

\begin{tabular}{lllll}
\multicolumn{5}{c}{ relative intensity } \\
$2 \theta(\mathrm{deg})$ & $h k l$ & $\mathrm{ZHA}\left(600^{\circ} \mathrm{C}\right)^{\mathrm{a}}$ & polycrystalline $\mathrm{ZnO}{ }^{\mathrm{b}}$ & lit. ZHA heated at $600^{\circ} \mathrm{C}^{\mathrm{c}}$ \\
31.9 & 100 & 0.55 & 0.57 & 0.1 \\
34.5 & 002 & 0.67 & 0.44 & 1.0 \\
36.4 & 101 & 1.00 & 1.00 & 0.3 \\
47.7 & 102 & 0.27 & 0.23 & 0.2 \\
56.8 & 110 & 0.33 & 0.32 & \\
63.1 & 103 & 0.36 & 0.29 &
\end{tabular}

${ }^{a}$ This work; sample heated at $20^{\circ} \mathrm{C} / \mathrm{min}$ in air to final temperature indicated. ${ }^{b}$ PDF no. $36-1451$, ref $33 .{ }^{c}$ Estimated from data presented in ref 30; sample heated for $60 \mathrm{~min}$.

Table 2. Average Crystallite Sizes of Metal Oxide Phases

\begin{tabular}{lllllll}
\multicolumn{7}{c}{ crystallite sizes $(\AA)$} \\
ZnO & & & $\mathrm{CuO}$ & $\mathrm{NiO}$ \\
precursor & $250^{\circ} \mathrm{C}$ & $300^{\circ} \mathrm{C}$ & $400^{\circ} \mathrm{C}$ & $600^{\circ} \mathrm{C}$ & $600^{\circ} \mathrm{C}$ & $600^{\circ} \mathrm{C}$ \\
ZHA & $322 \pm 24$ & $400 \pm 36$ & $419 \pm 39$ & $585 \pm 56$ & - & - \\
ZNA & $159 \pm 11$ & $145 \pm 13$ & $188 \pm 17$ & $482 \pm 48$ & - & $205 \pm 50$ \\
ZCA & $338 \pm 68$ & $361 \pm 45$ & $293 \pm 54$ & $496 \pm 62$ & $378 \pm 28$ & -
\end{tabular}

FTIR spectra of the residue obtained after calcinations of the ZHA to specified temperatures and that of bulk $\mathrm{ZnO}$ exposed to acetic acid vapor at room temperature for $2 \mathrm{~h}$, identified as $\mathrm{ZnO}-\mathrm{Ac}$, are shown in Figure 5. The FTIR spectrum obtained after heating ZHA to $250{ }^{\circ} \mathrm{C}$ can be assigned in analogy to acetate adsorbates on ZnO. $\frac{44}{A}$ weak but sharp $\mathrm{M}-\mathrm{O}$ absorption band is observed at $620 \mathrm{~cm}^{-1}$, weak and broad $\mathrm{M}-\mathrm{O}$ and $\delta\left(\mathrm{CH}_{3}\right)$ absorption bands are found at 700 and 
$1030 \mathrm{~cm}^{-1}$, respectively, and broadened symmetric and antisymmetric $\mathrm{C}-\mathrm{O}$ stretches occur at around 1420 and $1560 \mathrm{~cm}^{-1}$, respectively. The shift in position of the $\mathrm{C}-\mathrm{O}$ stretches, in comparison to the $\mathrm{ZHA}$ precursor, is consistent with the increase in interlayer spacing observed in the XRD data in Figure 4, ascribed to reorganization of the anions in the galleries. The most intense bands, assigned to the $\mathrm{C}-\mathrm{O}$ stretching modes, persisted in samples heated to $350{ }^{\circ} \mathrm{C}$, beyond the temperature where evidence for ZHA layered structures were observed in XRD analysis of residues. The combined FTIR spectra and XRD data for samples heated to 300 and $350^{\circ} \mathrm{C}$ suggest acetate in contact with $\mathrm{ZnO}$. A shoulder at $1460 \mathrm{~cm}^{-1}$ in the FTIR trace at $250{ }^{\circ} \mathrm{C}$ is also observed in the $\mathrm{ZnO}-\mathrm{Ac}$ spectrum, and this is consistent with adsorption of acetate groups on the $\mathrm{ZnO}$ surface during thermal decomposition. Peak assignments for the acetate anions bound to the $\mathrm{ZnO}$ surface are as follows. $1554 \mathrm{~cm}^{-1}$ (antisymmetric $\mathrm{O}-\mathrm{C}-\mathrm{O}$ stretching), $1460 \mathrm{~cm}^{-1}\left(\delta\left(\mathrm{CH}_{3}\right)\right), 1428 \mathrm{~cm}^{-1}$ (symmetric $\mathrm{O}-\mathrm{C}-\mathrm{O}$ stretching), and $1037 \mathrm{~cm}^{-1}\left(\delta\left(\mathrm{CH}_{3}\right)\right)$.

The similarity between FTIR spectra of $\mathrm{ZnO}-\mathrm{Ac}$ and bulk zinc acetate precludes a definitive assignment to either species. However, the absence of polycrystalline zinc acetate phases in the XRD patterns of the inorganic residues in this temperature regime suggests that ketonization occurs via surface adsorption of acetic acid over $\mathrm{ZnO}$. The basic nature of the $\mathrm{ZnO}$ surface promotes surface adsorption of acidic molecules providing catalytic sites over which ketonization progresses.

Loss of surface adsorbed and intercrystalline water molecules occur primarily in the temperature range of $50-150^{\circ} \mathrm{C}$ together with possible partial dehydroxylation of the precursor ZHA. In the temperature region of $150-250^{\circ} \mathrm{C}$, simultaneous dehydroxylation and deanation results in the formation of $\mathrm{ZnO}, \mathrm{ZnO}$ surface-adsorbed acetates ( $\mathrm{ZnO}-\mathrm{Ac})$, acetic acid, and water. At temperatures higher than $250{ }^{\circ} \mathrm{C}$, in addition to products mentioned above, evolution of $\mathrm{CO}_{2}$ and acetone is observed. This is attributed to the thermal decomposition of organic species and possible ketonization during the thermal decomposition process of ZHA in this temperature regime.

TGA and corresponding DTG curves of ZNA in air are shown in Figure 6A, while the DTA curve is shown in Figure 6B. ZNA is

Inorganic Chemistry, Vol 45, No. 9 (April 2006): pg. 3766-3773. DOI. This article is @ American Chemical Society and permission has been granted for this version to appear in e-Publications@Marquette. American Chemical Society does not grant permission for this article to be further copied/distributed or hosted elsewhere without the express permission from American Chemical Society. 
structurally similar to $\mathrm{ZHA}$; thus, it would be expected to show a similar thermal degradation pathway. One difference between these two precursors is the more evident third degradation step observed in the ZNA TGA data. For ZNA in air, a total mass loss of 8\% (calcd $6 \%$ based on elemental analysis of precursor) is observed between 50 and $150{ }^{\circ} \mathrm{C}$ and is attributed to the loss of physisorbed and intergallery water molecules. This is consistent with a DTA endothermic feature at around $140^{\circ} \mathrm{C}$, suggesting absorption of heat necessary to evaporate water molecules. A significant mass loss $(\sim 10 \%)$ in the $150-250{ }^{\circ} \mathrm{C}$ region is attributed to the loss of water and acetic acid.

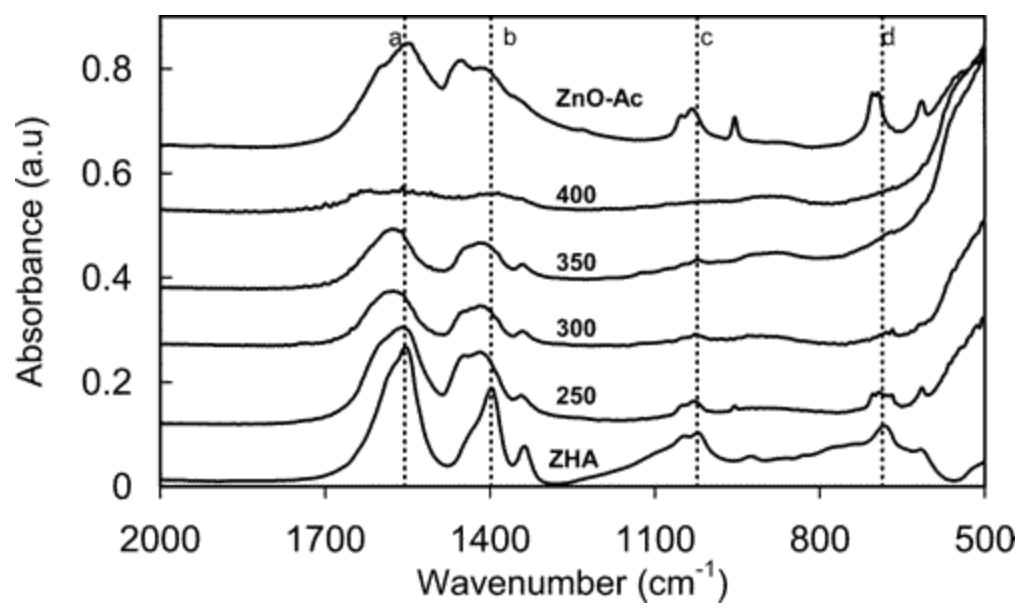

Figure 5 FTIR spectra of residual products collected after heating ZHA at $20{ }^{\circ} \mathrm{C} / \mathrm{min}$ in air to the indicated temperature $\left({ }^{\circ} \mathrm{C}\right.$ ). Reference spectra for ZHA precursor (bottom trace) and for $\mathrm{ZnO}$ exposed to acetic acid vapor (top trace) are also provided. Dotted vertical lines indicate absorption band positions for $\mathrm{O}-\mathrm{C}-\mathrm{O}$ antisymmetric (a) and symmetric stretch (b), respectively, deformation mode $\left(\delta\left(\mathrm{CH}_{3}\right)\right)(\mathrm{c})$, and $\mathrm{Zn}-\mathrm{O}$ stretch (d) in the precursor ZHA.

Inorganic Chemistry, Vol 45, No. 9 (April 2006): pg. 3766-3773. DOI. This article is (C) American Chemical Society and permission has been granted for this version to appear in e-Publications@Marquette. American Chemical Society does not grant permission for this article to be further copied/distributed or hosted elsewhere without the express permission from American Chemical Society. 
NOT THE PUBLISHED VERSION; this is the author's final, peer-reviewed manuscript. The published version may be accessed by following the link in the citation at the bottom of the page.

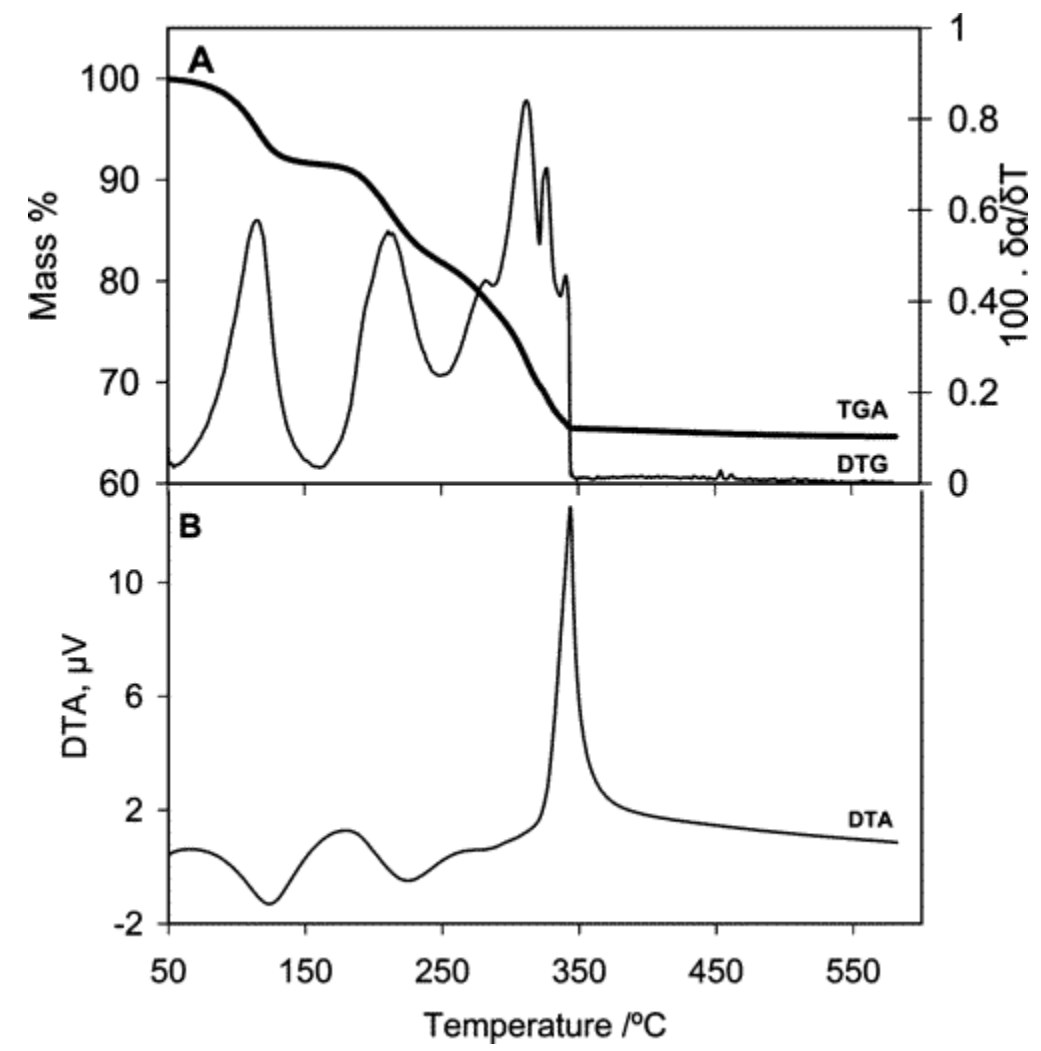

Figure 6 (A) TGA and corresponding DTG curves of ZNA from 50 to $600{ }^{\circ} \mathrm{C}$ at $20^{\circ} \mathrm{C} / \mathrm{min}$ in air. (B) DTA curve for ZNA from 50 to $600^{\circ} \mathrm{C}$ at $20^{\circ} \mathrm{C} / \mathrm{min}$ in air.

Multiple weight losses totaling $17 \%$ are observed in the region of $250-350{ }^{\circ} \mathrm{C}$ with simultaneous loss of water, acetic acid, and acetone in the earlier stages followed by the evolution of $\mathrm{CO}_{2}$ at temperatures above $300^{\circ} \mathrm{C}$, as shown in the FTIR spectra of TGA evolved gases shown in Figure 7. A weak DTA endothermic feature at $230{ }^{\circ} \mathrm{C}$ and a vigorous exothermic peak at $340{ }^{\circ} \mathrm{C}$ in Figure $6 \mathrm{~A}$ correspond to the complete thermal decomposition of ZNA resulting from the loss of $\mathrm{OH}$ ions bound to $\mathrm{Ni}^{2+}$ and the decomposition of the acetate anions, respectively. $\underline{45}$ 


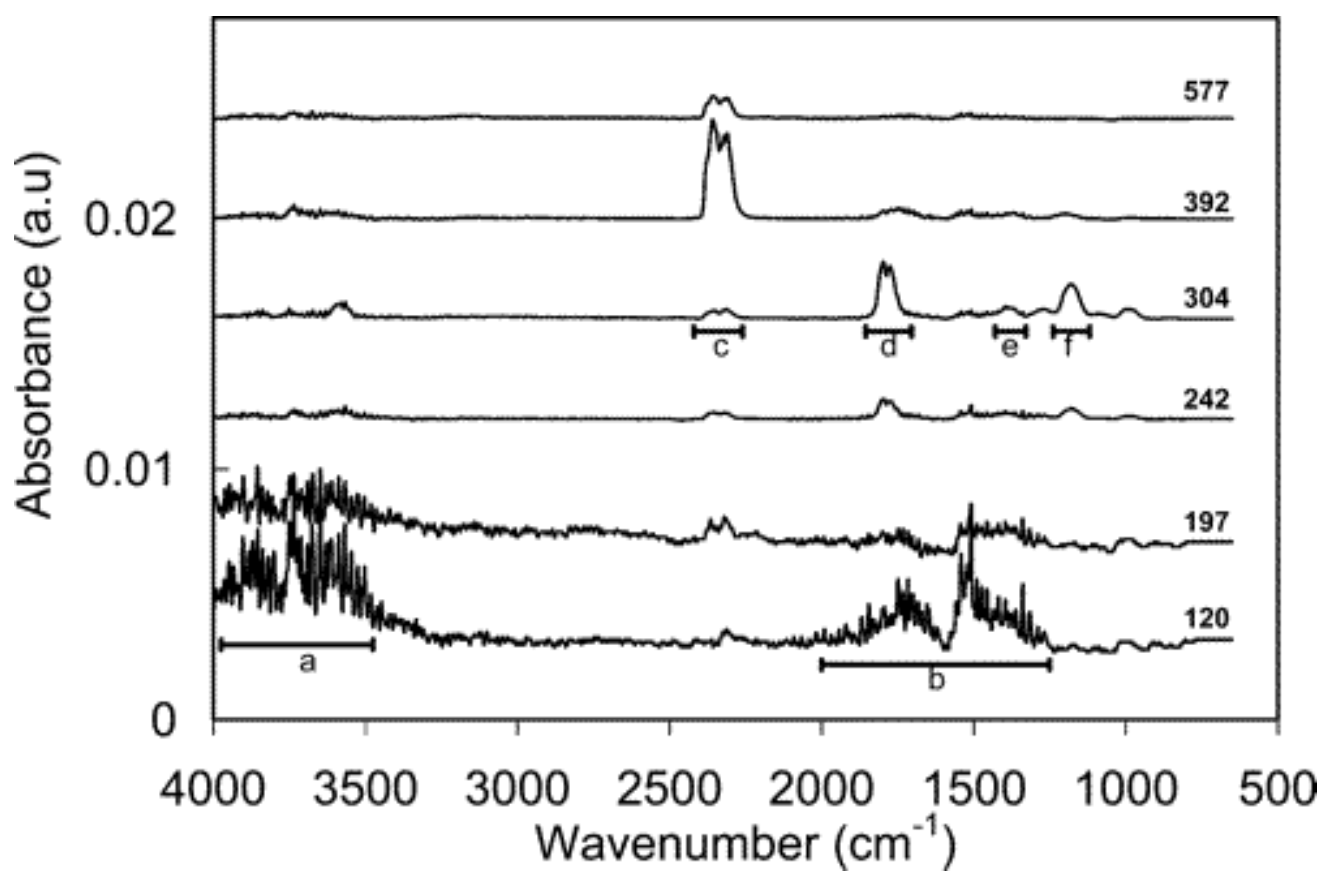

Figure 7 FTIR spectra of evolved gaseous products collected at the temperature $\left({ }^{\circ} \mathrm{C}\right)$ indicated on the right of each spectrum during thermal combustion of ZNA in air $\left(20^{\circ} \mathrm{C} / \mathrm{min}\right)$. FTIR spectra were scaled by dividing by 10 except for those at 120 and $197^{\circ} \mathrm{C}$ which were not scaled. Expected positions of absorption bands for water stretching modes (a), bending mode (b), $\mathrm{CO}_{2}$ antisymmetric stretch (c), overlapping acetic acid and acetone $\mathrm{C}=\mathrm{O}$ stretch (d), $\mathrm{CH}_{3}$ deformation (e), and $\mathrm{C}-\mathrm{C}$ bending for acetone and $\mathrm{C}-\mathrm{O}$ stretch for acetic acid (f) are shown.

Data obtained from XRD analysis of solid residues obtained at various points in the heating ramp for ZNA are shown in Figure 8. At 150 and $200{ }^{\circ} \mathrm{C}$, the XRD patterns indicate the presence of the polycrystalline layered ZNA phase. After heating to $250^{\circ} \mathrm{C}$, ZNA and $\mathrm{ZnO}$ (marked in empty diamonds) are observed. Complete collapse of layered structure occurs at $300{ }^{\circ} \mathrm{C}$, yielding polycrystalline $\mathrm{ZnO}$ and $\mathrm{NiO}$ (marked in empty squares; PDF no. 47-1049). ${ }^{33}$ Further heating in the range of $300-600{ }^{\circ} \mathrm{C}$ yields $\mathrm{ZnO}$ and $\mathrm{NiO}$. Average crystallite sizes of the metal oxide phases are summarized in Table 2 . The crystallite size of $\mathrm{ZnO}$ was found to be $145 \pm 13 \AA$ after heating to $300{ }^{\circ} \mathrm{C}$ and increased to $482 \pm 48 \AA$ after heating to $600{ }^{\circ} \mathrm{C}$. The crystallite size of $\mathrm{NiO}$ after heating to $600{ }^{\circ} \mathrm{C}$ was calculated to be $205 \pm 50 \AA$ using the nonoverlapping 200 reflection of $\mathrm{NiO}$ at $43.2^{\circ}$. The presence of $\mathrm{Ni}^{2+}$ in the intralayer of ZNA retards growth of the $\mathrm{ZnO}$ phase, with crystallite sizes observed to be one-half or less of the average sizes obtained from ZHA at temperatures up to $400^{\circ} \mathrm{C}$. 


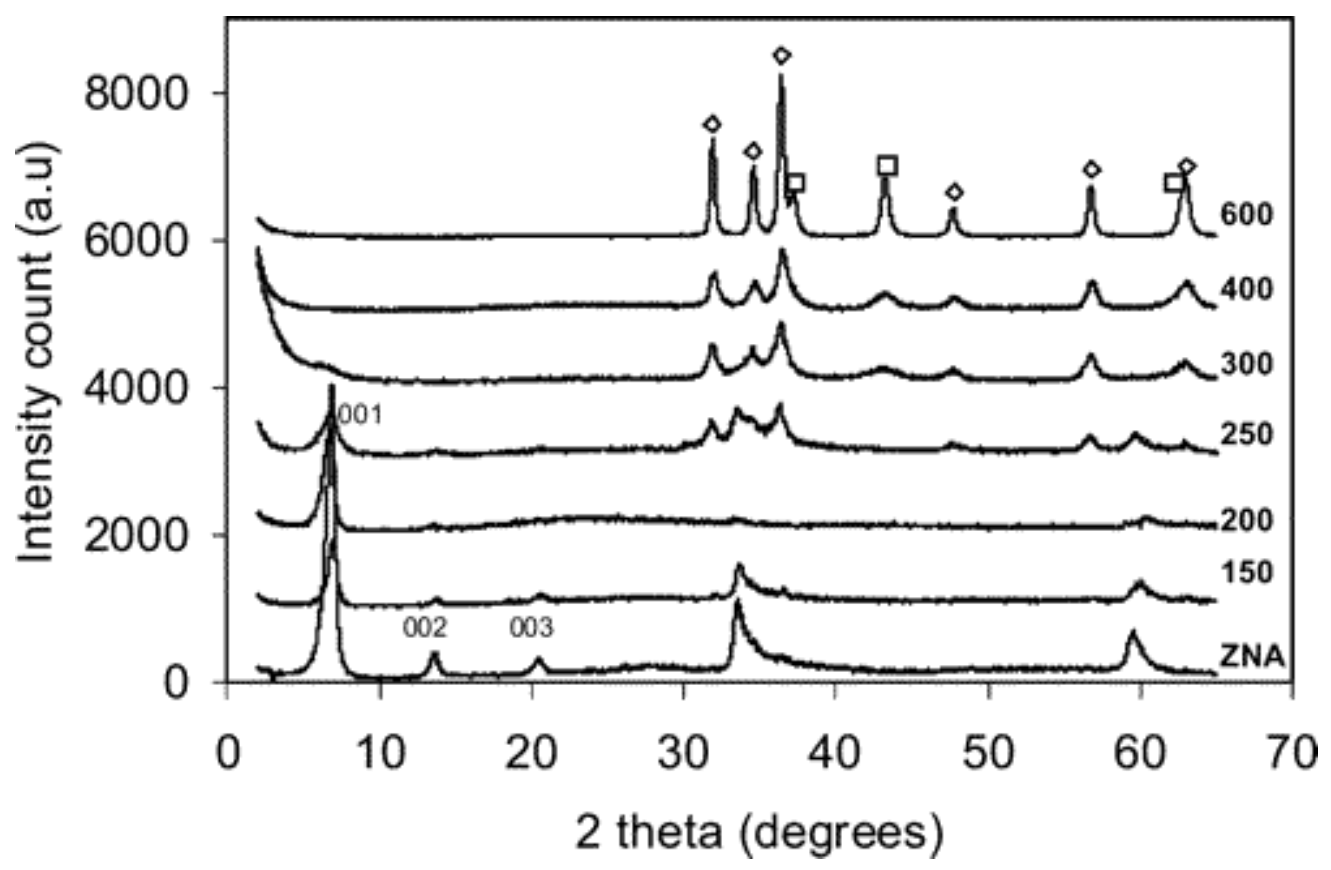

Figure 8 XRD analysis of the inorganic residue from heating ZNA in air to temperatures indicated; trace for the residue at $600^{\circ} \mathrm{C}$ shows $\mathrm{ZnO}$ reflections $(\diamond)$ and $\mathrm{NiO}$ reflections ( $\square)$.

Careful inspection of FTIR spectra of the gas-phase products evolved in the temperature region of $300-400^{\circ} \mathrm{C}$ (Supporting Information) reveals some differences in the profile for evolution of acetic acid, acetone, $\mathrm{CO}_{2}$, and water from ZNA when compared with ZHA. Evolution of acetic acid from ZNA begins at temperatures $<250{ }^{\circ} \mathrm{C}$. There is a temperature shift in terms of the relative contributions of deanation versus ketonization channels for the ZNA relative to ZHA. Examination of the relative intensities of the carbonyl stretching bands centered at 1788 and $1730 \mathrm{~cm}^{-1}$ for acetic acid and acetone, respectively, suggests that, for temperatures below $340^{\circ} \mathrm{C}$, the production of acetone relative to acetic acid from ZNA is lower than that observed at the same temperature from ZHA. Further work is necessary to quantify yields. However, when combined with the XRD analysis of solid residues, which exhibit smaller $\mathrm{ZnO}$ average crystallite size for ZNA, the pattern of gas-phase product evolution suggests that the presence of $\mathrm{ZnO}$ catalytic surface is responsible for promoting ketonization.

FTIR spectra of solid residues of ZNA obtained at different points in the heating ramp and $\mathrm{ZnO}-\mathrm{Ac}$ are shown in Figure 9. The FTIR 
trace for the sample heated to $300{ }^{\circ} \mathrm{C}$ suggests adsorption of acetic acid moieties on the $\mathrm{ZnO}$ surface leading to its ketonization. $\mathrm{CO}_{2}$ produced during ketonization may then bind to $\mathrm{ZnO}$, forming a metal carbonate species, as evident from a very broad absorption band $\left(1250-1800 \mathrm{~cm}^{-1}\right)$ in the FTIR trace at $350{ }^{\circ} \mathrm{C} . .^{40}$ The continuous release of $\mathrm{CO}_{2}$ and water at temperatures above $400{ }^{\circ} \mathrm{C}$ may be attributed to the thermo-oxidative degradation of organic species such as acetone.

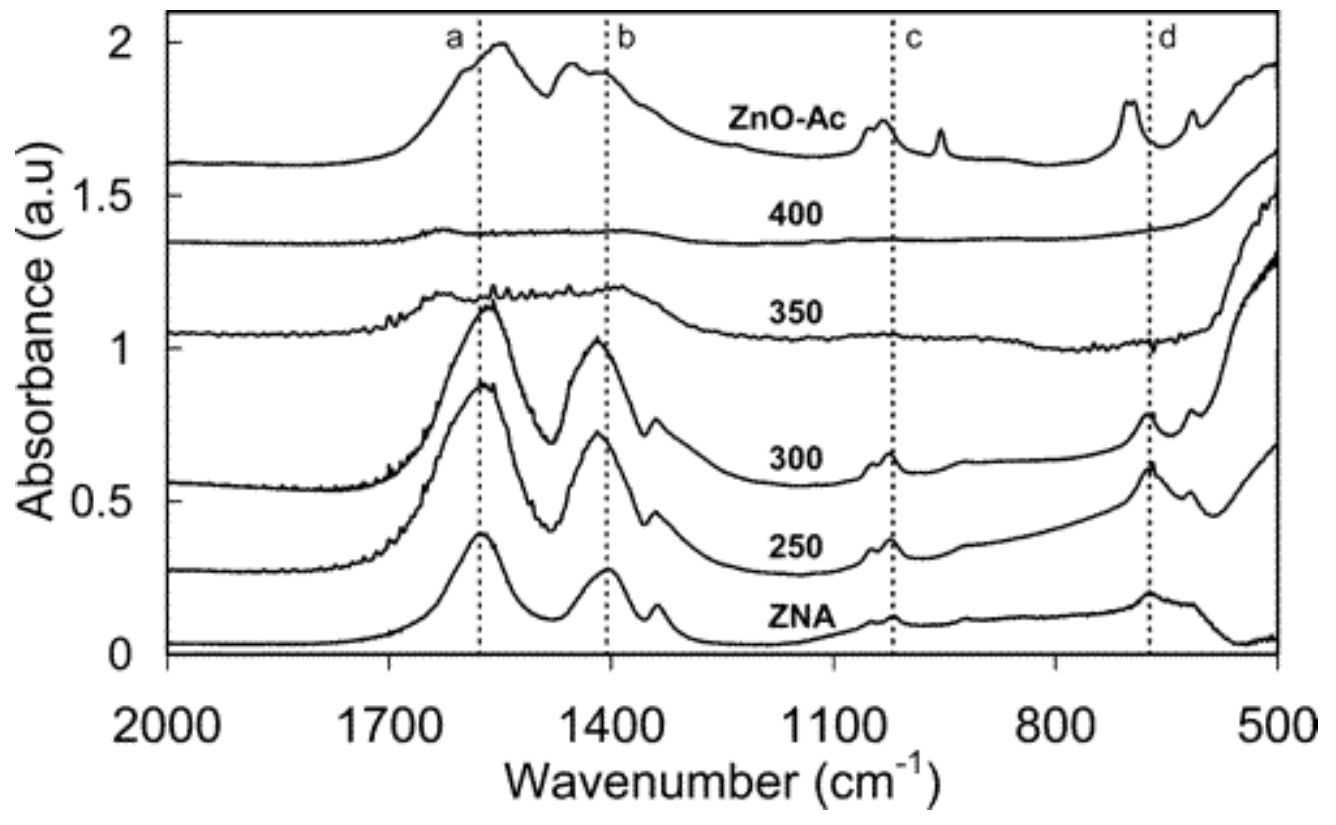

Figure 9 FTIR spectra of residual products collected after heating ZNA at $20{ }^{\circ} \mathrm{C} / \mathrm{min}$ in air to the indicated temperature $\left({ }^{\circ} \mathrm{C}\right.$ ). Reference spectra for ZNA precursor (bottom trace) and for $\mathrm{ZnO}$ exposed to acetic acid vapor (top trace) are also provided. Dotted vertical lines indicate absorption band positions for $\mathrm{O}-\mathrm{C}-\mathrm{O}$ anti-symmetric (a) and symmetric stretch (b), respectively, deformation mode $\left(\delta\left(\mathrm{CH}_{3}\right)\right)(\mathrm{c})$, and $\mathrm{Zn}-\mathrm{O}$ stretch (d) in the precursor ZNA.

TGA and corresponding DTG curves of ZCA in air are shown in Figure 10A, with corresponding DTA data provided in Figure 10B. A 7\% mass loss in the temperature range of $50-150{ }^{\circ} \mathrm{C}$ in air, Figure $10 \mathrm{~A}$, is attributed to the dehydration process resulting from the loss of surface and interlayer water molecules consistent with a DTA endothermic feature at about $140{ }^{\circ} \mathrm{C}$ shown in Figure 10B. The weight increase observed at temperatures above $400{ }^{\circ} \mathrm{C}$ is due to oxidation of $\mathrm{Cu}$ and $\mathrm{Cu}_{2} \mathrm{O}$ to $\mathrm{CuO}$. 


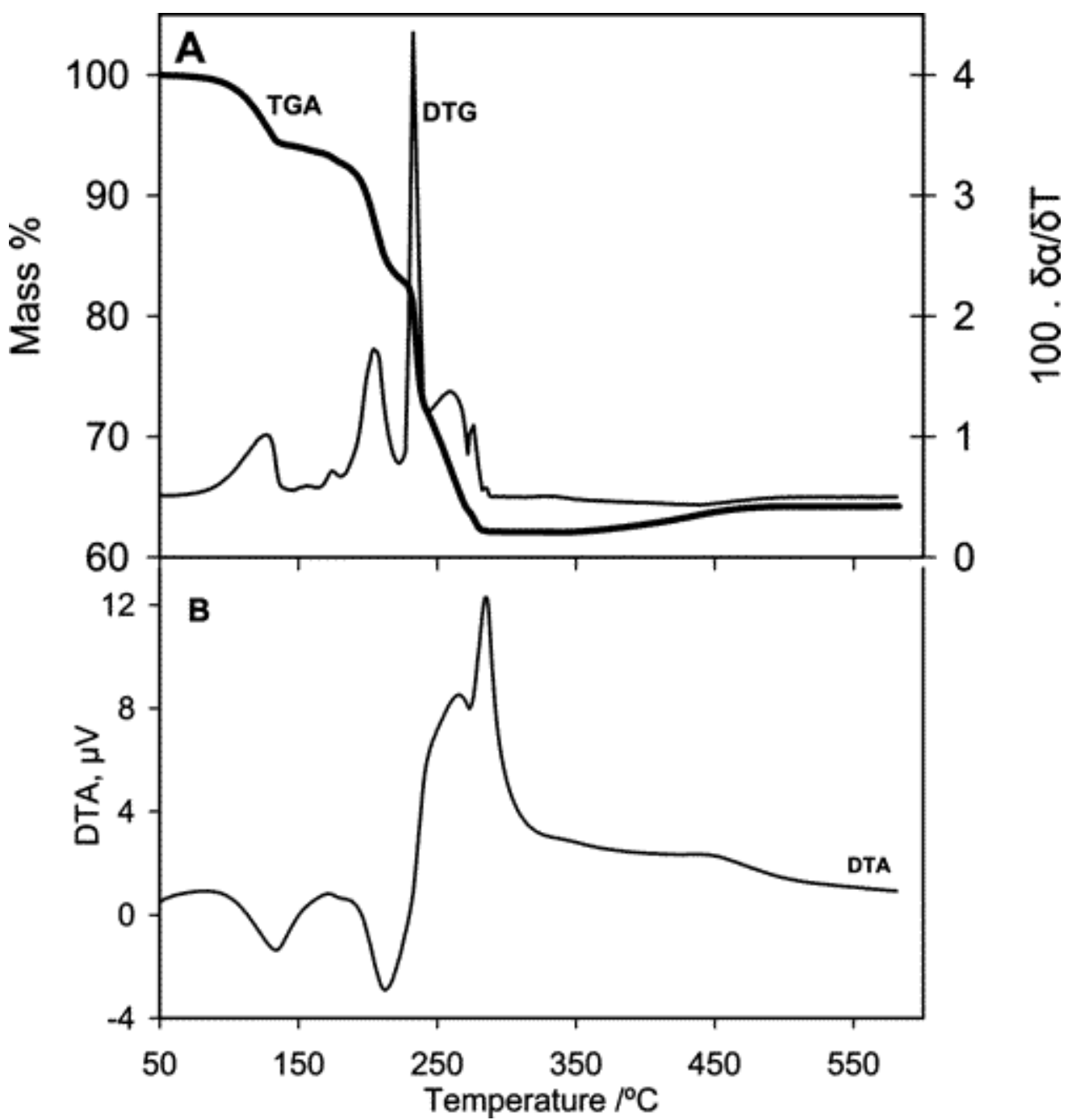

Figure 10 (A) TGA and corresponding DTG curves of ZCA from 50 to $600{ }^{\circ} \mathrm{C}$ at $20^{\circ} \mathrm{C} / \mathrm{min}$ in air. (B) DTA curve for ZCA from 50 to $600^{\circ} \mathrm{C}$ at $20^{\circ} \mathrm{C} / \mathrm{min}$ in air.

FTIR spectra of gas-phase products formed at 121 and $192{ }^{\circ} \mathrm{C}$, shown in Figure 11, reveal that water is the primary product in this temperature range. A second endothermic degradation step that begins at around $200{ }^{\circ} \mathrm{C}$ is consistent with both deanation and dehydroxylation, with water and acetic acid observed in the FTIR spectra in this temperature range. The DTA curve for ZCA in air shows two overlapping exothermic peaks between 230 and $320^{\circ} \mathrm{C}$. The final step just above $230^{\circ} \mathrm{C}$ is consistent with the loss of organic anions through deanation and/ or thermo-oxidation, leading to the formation of $\mathrm{CO}_{2}$ and $\mathrm{H}_{2} \mathrm{O}$, as evident from a sharp weight loss occurring at $240{ }^{\circ} \mathrm{C}$ accompanied by an exothermic feature in the DTA curve. FTIR permission has been granted for this version to appear in e-Publications@Marquette. American Chemical Society does not grant permission for this article to be further copied/distributed or hosted elsewhere without the express permission from American Chemical Society. 
spectra shown in Figure 11 (with additional spectra provided as Supporting Information) show that acetic acid, water, and $\mathrm{CO}_{2}$ are the primary products in the temperature range of $250-400{ }^{\circ} \mathrm{C}$ with very little formation of acetone.

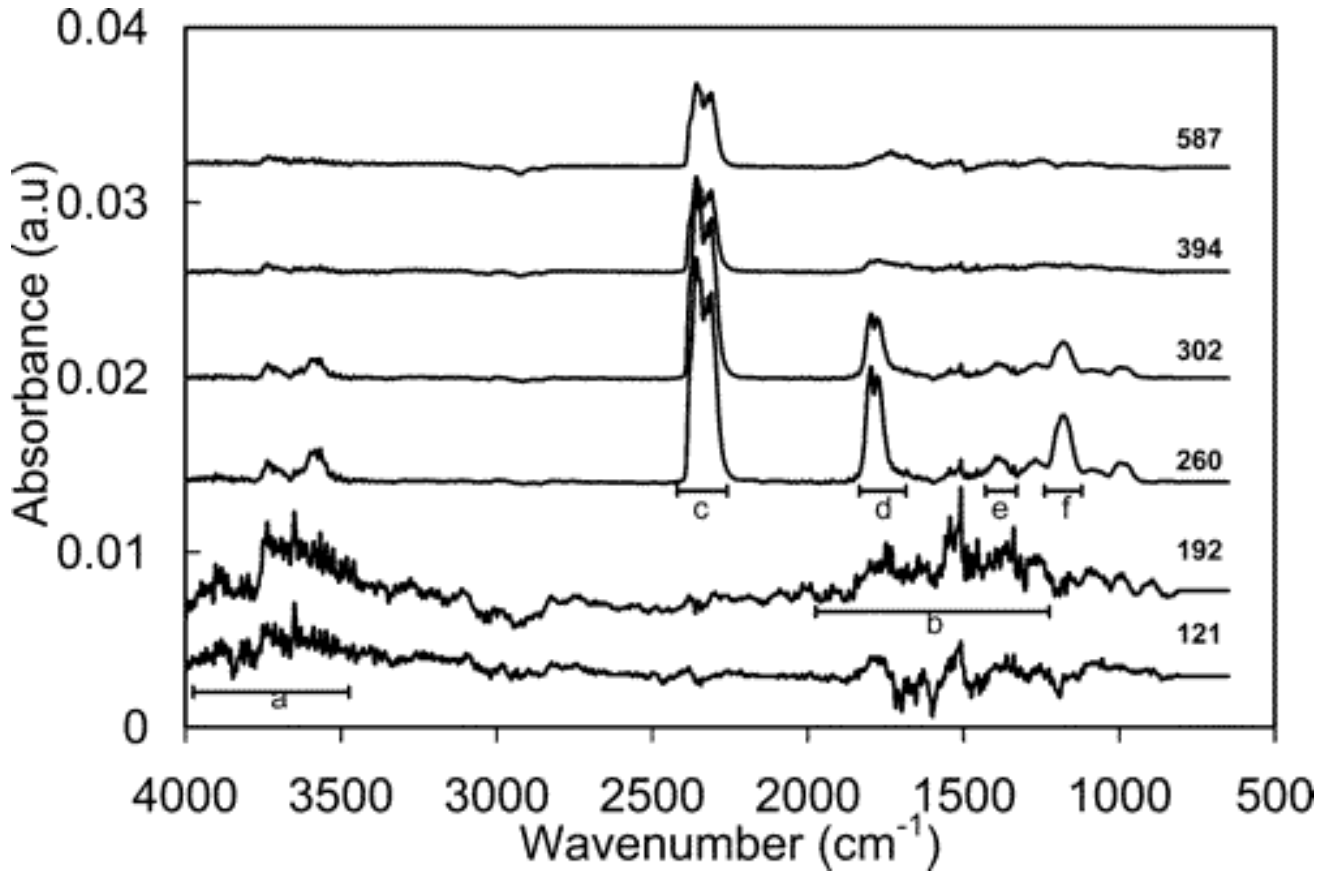

Figure 11 FTIR spectra of evolved gaseous products collected at the temperature $\left({ }^{\circ} \mathrm{C}\right)$ indicated on the right of each spectrum during thermal combustion of ZCA in air $\left(20^{\circ} \mathrm{C} / \mathrm{min}\right)$. FTIR spectra were scaled by dividing by 10 except for those at 121 and $192{ }^{\circ} \mathrm{C}$ which were not scaled. Expected positions of absorption bands for water stretching modes (a), bending mode (b), $\mathrm{CO}_{2}$ antisymmetric stretch (c), overlapping acetic acid and acetone $\mathrm{C}=\mathrm{O}$ stretch (d), $\mathrm{CH}_{3}$ deformation (e), and $\mathrm{C}-\mathrm{C}$ bending for acetone and $\mathrm{C}-\mathrm{O}$ stretch for acetic acid (f) are shown.

XRD patterns of the inorganic residue in air after heating to various temperatures are shown in Figure 12. The XRD data for the residue obtained from heating $Z C A$ to $150{ }^{\circ} \mathrm{C}$ reveal the presence of ZCA as the only polycrystalline product. Heating to $200{ }^{\circ} \mathrm{C}$ yields an amorphous product showing a broad feature at $6.6^{\circ}$ corresponding to an unidentified phase. Note that the ZCA layered structure disappears at an earlier temperature than it does for ZHA or ZNA. Weak, broad $\mathrm{ZnO}$ features are observed after heating to $250{ }^{\circ} \mathrm{C}$, along with metallic copper (labeled with asterisks in Figure 12; PDF no. 4-836) ${ }^{33}$ and $\mathrm{Cu}_{2} \mathrm{O}$ (open triangles triangles; PDF no. 35-1091). ${ }^{33}$ Simultaneous presence of metallic copper, $\mathrm{Cu}_{2} \mathrm{O}$, and $\mathrm{ZnO}$ suggests macroscopic heterogeneity. After heating to $600^{\circ} \mathrm{C}, \mathrm{ZnO}$ and $\mathrm{CuO}$ are the only polycrystalline phases formed. 


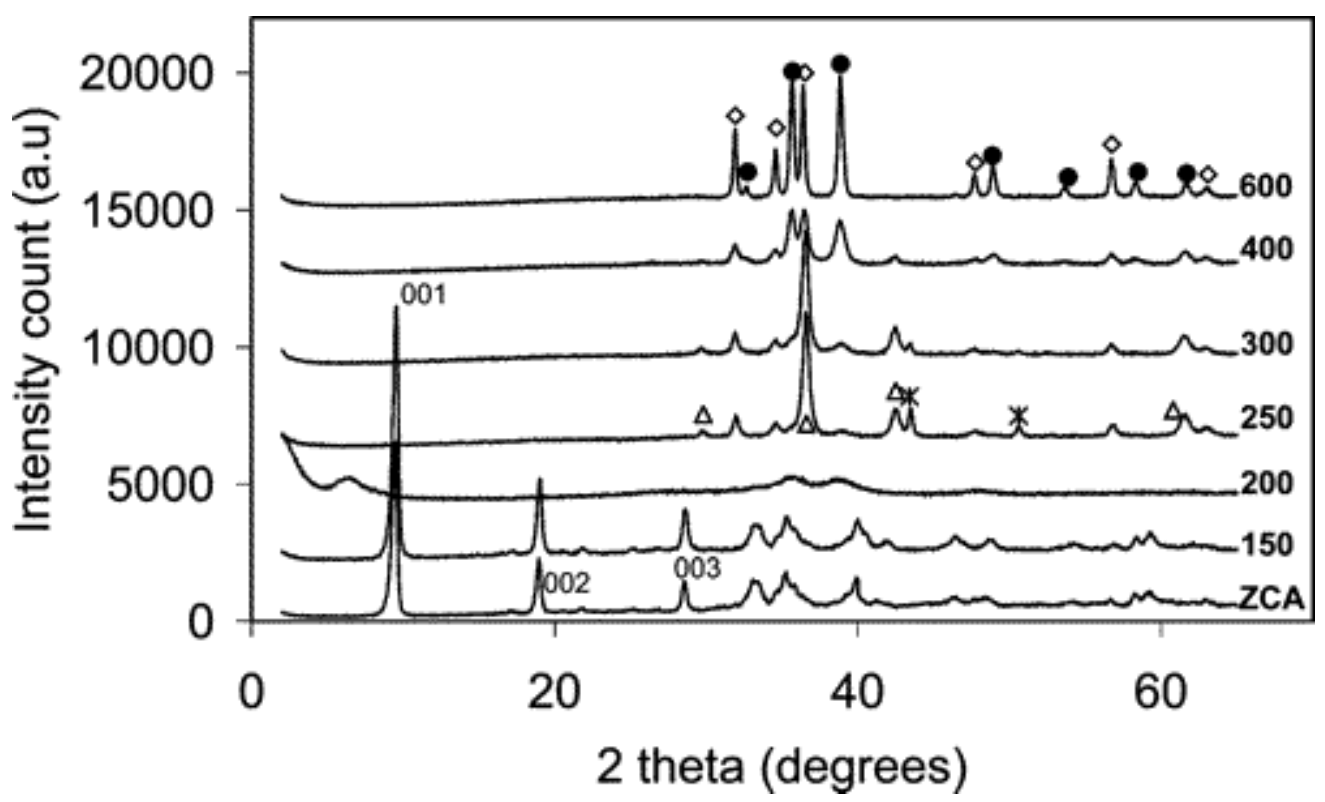

Figure 12 XRD analysis of the residue from thermal combustion of ZCA in air; the temperatures to which ZCA was heated are indicated. Only $\mathrm{ZnO}(\diamond)$ and $\mathrm{CuO}(\cdot)$ were observed after heating to $600{ }^{\circ} \mathrm{C}$. Peaks assigned to metallic copper $(*)$ and $\mathrm{Cu}_{2} \mathrm{O}(\square)$ were observed in samples heated to 250 and $300^{\circ} \mathrm{C}$.

Results reported herein are similar to those observed by Guo and co-workers from the calcination of $\mathrm{Zn}\left[\mathrm{Cu}(\mathrm{CN})_{3}\right] .{ }^{5} \mathrm{Cu}$ is oxidized to $\mathrm{Cu}_{2} \mathrm{O}$, which in turn is oxidized to $\mathrm{CuO}$ as a result of direct contact with oxygen. The approximate crystallite sizes of $\mathrm{ZnO}$ and $\mathrm{CuO}$ particles obtained from ZCA after heating to $600^{\circ} \mathrm{C}$ in air are $496 \pm 62$ and 378 $\pm 28 \AA$, respectively. When fitting the XRD data to extract peak widths for determination of average crystallite size of $\mathrm{ZnO}$, the overlapping $\mathrm{ZnO}(100)$ and $\mathrm{CuO}$ (110) reflections were fit simultaneously. However, the overlapping peaks and relatively weak $\mathrm{ZnO}$ reflections lead to larger uncertainty in the extracted crystallite sizes indicated in Table 2. Within the uncertainty limits, there appears to be little $\mathrm{ZnO}$ crystallite growth until $600^{\circ} \mathrm{C}$, as was also observed with ZNA, possibly due to phase separation effects.

FTIR spectra of the residues obtained when heating ZCA are shown in Figure 13. The inorganic residues at temperatures above $250{ }^{\circ} \mathrm{C}$ are acetate-free. There is no evidence of either metal acetate formation or adsorption of the acetate anions on metal oxides, consistent with the minimal acetone production observed from this precursor. Instead, carbonate-containing species are seen at temperatures of $300^{\circ} \mathrm{C}$ and beyond probably as a result of permission has been granted for this version to appear in e-Publications@Marquette. American Chemical Society does not grant permission for this article to be further copied/distributed or hosted elsewhere without the express permission from American Chemical Society. 
combination of $\mathrm{CO}_{2}$ with metal oxides. ${ }^{40}$ This might explain the relative lack of ketonization observed for this system. Metallic copper and CuO have been reported to have no catalytic effect on the ketonization of

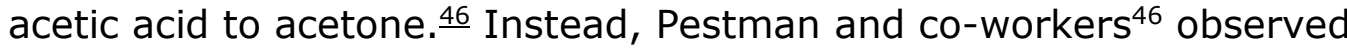
that $\mathrm{CuO}$ promotes formation of acetaldehyde from acetic acid. In the same work, copper in its partially reduced form, $\mathrm{Cu}_{2} \mathrm{O}$, has been shown to promote ketonization. Even though $\mathrm{Cu}_{2} \mathrm{O}$ is present in the temperature region over which acetic acid is released, its concomitant presence with metallic copper and/or CuO or the existence of bound carbonate species may render it inactive. In addition, ZCA has the smallest mole fraction of zinc of the three model compounds investigated, limiting the $\mathrm{ZnO}$ surface area available for catalyzing the ketonization channel.

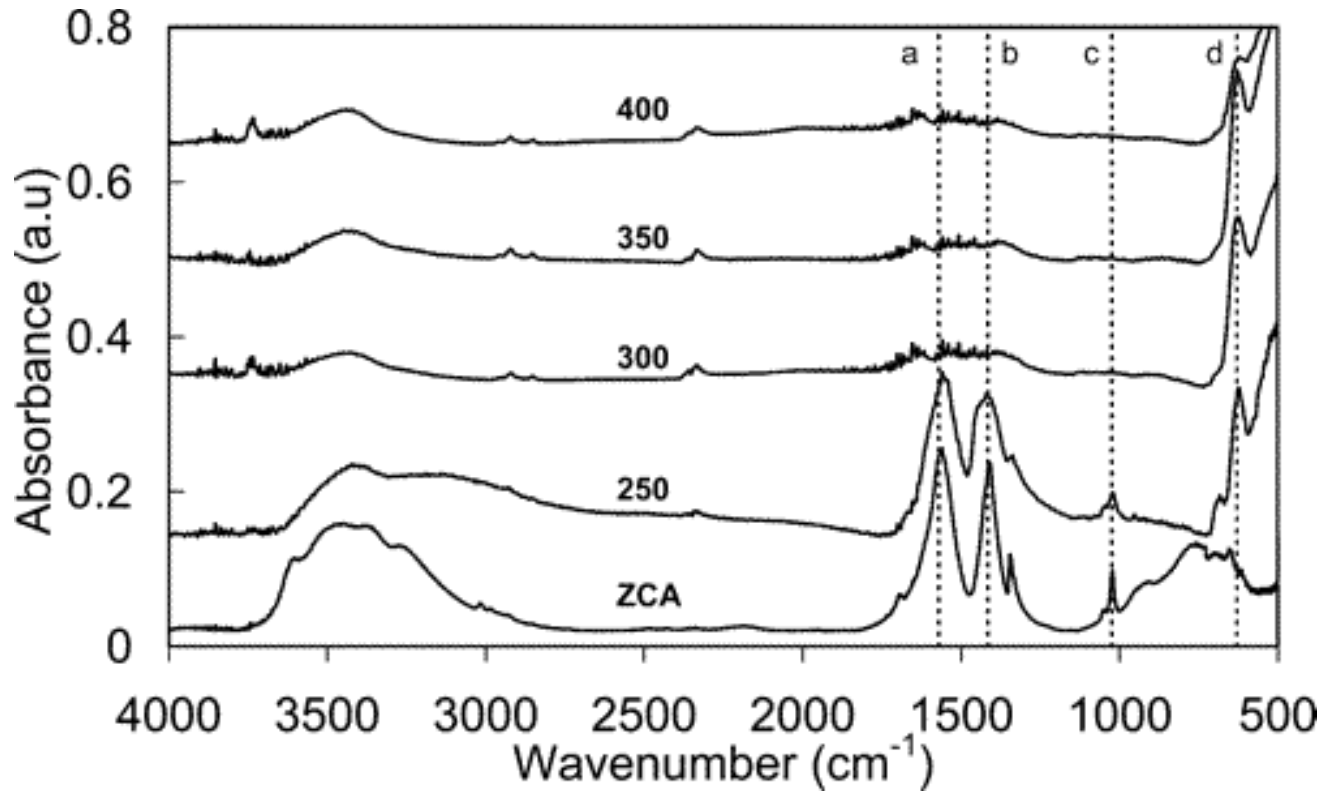

Figure 13 FTIR spectra of residual products collected after heating ZCA at $20^{\circ} \mathrm{C} / \mathrm{min}$ in air to the indicated temperature $\left({ }^{\circ} \mathrm{C}\right)$. Reference spectrum for ZCA precursor (bottom trace) is also provided. Dotted vertical lines indicate absorption band positions for $\mathrm{O}-\mathrm{C}-\mathrm{O}$ antisymmetric (a) and symmetric stretch (b), respectively, deformation mode $\left(\delta\left(\mathrm{CH}_{3}\right)\right)(\mathrm{c})$, and $\mathrm{Zn}-\mathrm{O}$ stretch (d) in the precursor ZCA.

Surface-adsorbed and intercrystalline water molecules are largely lost in the temperature range of $50-150{ }^{\circ} \mathrm{C}$. Decomposition of ZCA via dehydroxylation and deanation in the $150-400{ }^{\circ} \mathrm{C}$ temperature region results in the formation of $\mathrm{ZnO}, \mathrm{CuO}$, and reduced copper-containing species, $\mathrm{Cu}, \mathrm{Cu}_{2} \mathrm{O}$. Acetic acid, water, and $\mathrm{CO}_{2}$ are evolved during the thermal decomposition at elevated temperatures. Very little acetone is observed, suggesting that calcination of ZCA does 
not promote ketonization. Polycrystalline $\mathrm{ZnO}$ and $\mathrm{CuO}$ are the final solid residues remaining after heating to $600^{\circ} \mathrm{C}$ or higher.

While heating ZCA did not promote ketonization, we note the reduced metal species observed in the thermal degradation process. The presence of reduced metallic species has been shown to play an important role in thermal stabilization of polymeric composites. ${ }^{10-13,47,48}$ Klenov and co-workers $\underline{49}$ reported the appearance of $\mathrm{Cu}(\mathrm{I})$ and metallic copper on the surface of the $\mathrm{Cu}^{2+}$-containing $\mathrm{ZnO}$ after catalyst reduction and they believe these species play an important role in the catalytic synthesis of methanol from $\mathrm{H}_{2}$ and $\mathrm{CO}$. The formation of reduced copper is thus important for enhancing selected chemical pathways.

Some of the key differences in structure between ZHA, ZNA, and ZCA were discussed in our previous report. ${ }^{38}$ FTIR spectra suggest that the bonding of the acetate to the metal centers in the gallery spacing is pseudo-bridging in ZCA with one acetate oxygen bound to $\mathrm{Cu}^{2+}$ and the other acetate oxygen forming a hydrogen bond with an adjacent $\mathrm{OH}$ group from the metal hydroxide layer, similar to that reported ${ }^{37}$ for $\mathrm{Cu}_{2}(\mathrm{OH})_{3}\left(\mathrm{CH}_{3} \mathrm{CO}_{2}\right) \cdot \mathrm{H}_{2} \mathrm{O}$. ZHA and ZNA spectra were more consistent with unidentate binding; ${ }^{38}$ however, the possibility of hydrogen-bonding interaction of the "free" carbonyl oxygen cannot be precluded on the basis of the FTIR data. DTA curves from thermal degradation of ZCA in air reported here exhibit a pronounced endothermic event around $210^{\circ} \mathrm{C}$, which was not observed for ZHA and barely observed for the ZNA thermal degradation in air. This is consistent with a stronger anion-cation interaction for the ZCA HDS as compared to ZHA and ZNA. The departure of the acetate anion without decomposition requires more energy if it were tightly bound to the metal center as assumed in ZCA, while less energy will be required for the same processes when the interaction between the metal center and the anion is weaker, as predicted for ZHA and ZNA.

\section{Conclusions}

The thermal degradation of zinc-containing layered hydroxy salt or hydroxy double salts with interlayer acetate depends on the structure/composition of the metal hydroxide layer. The initial thermal 
degradation step for ZHA, ZNA, and ZCA is loss of intercalated water in the temperature range of $50-150{ }^{\circ} \mathrm{C}$. Other gas-phase products observed at higher temperatures include acetic acid, acetone, $\mathrm{CO}_{2}$, and $\mathrm{H}_{2} \mathrm{O}$, and the solid residues contain a mixture of metal oxide phases. Catalytic ketonization of acetic acid to form acetone is observed for ZHA and ZNA, with slightly higher temperatures required for the ketonization channel in ZNA. Little acetone was observed in the thermal decomposition of ZCA. Combined FTIR and XRD analysis of solid residues extracted at different points in the heating profile suggests that ketonization occurs via dissociative adsorption of acetic acid on ZnO surfaces.

$\mathrm{ZnO}$ from the thermal degradation of ZHA revealed a slight preferential growth in (002) lattice dimension. Inclusion of the other metals ( $\mathrm{Ni}$ and $\mathrm{Cu}$ ) in the HDS structure containing $\mathrm{Zn}$ eliminated preferential crystal growth in any lattice directions for $\mathrm{ZnO}$ and also served to retard the $\mathrm{ZnO}$ crystallite growth. In the case of ZCA, reduced copper species, $\mathrm{Cu}_{2} \mathrm{O}$ and metallic copper, were observed in the thermal degradation of ZCA at $250-500{ }^{\circ} \mathrm{C}$ in an air atmosphere with oxidation to $\mathrm{CuO}$ completed by $600^{\circ} \mathrm{C}$.

\section{Acknowledgment}

We thank Marquette University Committee on Research for partial support of this work and J. Collins for support of the X-ray diffractometer.

\section{References}

${ }^{1}$ Rives, V. In Layered Double Hydroxides: Present and Future; Nova: New York, 2001.

${ }^{2}$ Reichle, W. T. J. Catal. 1985, 94, 547.

3̂Kappenstein, C.; Cernak, J.; Brahmi, R.; Duprez, D.; Chomic, J. Thermochim. Acta 1996, 276, 65.

${ }^{4}$ Cernak, J.; Chomic, J.; Kappenstein, C.; Brahmi, R.; Duprez, D. Thermochim. Acta 1996, 276, 209.

5Guo, Y.; Weiss, R.; Epple, M. Eur. J. Inorg. Chem. 2005, 3072.

${ }^{6}$ Crepaldi, E. L.; Pavan, P. C.; Valim, J. B. Mater. Chem. 2000, 10, 1337.

ZMorioka, H.; Tagaya, H.; Kadokawa, J.; Chiba, K. Recent Res. Dev. Mater.

Sci. 1998, 1, 137.

8Bruschini, C. S.; Hudson, M. J. Progress in Ion Exchange Special Publication; Royal Society of Chemistry: London, 1997; Vol. 196, p 403. permission has been granted for this version to appear in e-Publications@Marquette. American Chemical Society does not grant permission for this article to be further copied/distributed or hosted elsewhere without the express permission from American Chemical Society. 
NOT THE PUBLISHED VERSION; this is the author's final, peer-reviewed manuscript. The published version may be accessed by following the link in the citation at the bottom of the page.

9Meyn, M.; Beneke, K.; Lagaly, G. Inorg. Chem. 1993, 32, 1209.

${ }^{10}$ Kandare, E.; Deng, H.; Wang, D.; Hossenlopp, J. M. Polym. Adv. Tech. 2005, in press.

11 Kandare, E.; Hall, D.; Jiang, D. D.; Hossenlopp, J. M. In Fire and Polymers IV: Materials and Concepts for Hazard Prevention; Wilkie, C. A., Nelson, G. L., Eds.; ACS Symposium Series, Oxford University Press: New York, 2006.

12 Kandare, E.; Chigwada, G.; Wang, D.; Wilkie, C. A.; Hossenlopp, J. M. Polym. Degrad. Stab. 2006, 91, 1209.

13 Kandare, E.; Chigwada, G.; Wang, D.; Wilkie, C. A.; Hossenlopp, J. M. Polym. Degrad. Stab. 2006, in press.

${ }^{14}$ Constantino, V. R. L.; Pinnavaia, T. J. Inorg. Chem. 1995, 34, 883.

15Del Arco, M.; Malet, P.; Trujillano, R.; Rives, V. Chem. Mater. 1999, 11, 624.

${ }^{16}$ Chellam, U.; Xu, Z. P.; Zeng, H. C. Chem. Mater. 2000, 12, 650.

17Labajos, F. M.; Rives, V.; Malet, P.; Centeno, M. A.; Ulibarri, M. A. Inorg. Chem. 1996, 35, 1154.

18 Prevot, V.; Forano, C.; Besse, J. P. Chem. Mater. 2005, 17, 6695.

19 Kovanda, F.; Rojka, T.; Dobesova, J.; Machovic, V.; Bezdicka, P.; Obalova, L.; Jiratova, K.; Grygar, T. J. Solid State Chem. 2006, 179, 812.

${ }^{20}$ Sileo, E. E.; Jobbagy, M.; Paiva-Santos, C. O.; Regazzoni, A. E. J. Phys. Chem. B. 2005, 109, 10137.

21Lin, Y.; Adebajo, M. O.; Frost, R. L.; Kloprogge, J. T. J. Therm. Anal. Cal. 2005, 81, 83.

22Arii, Tadashi.; Kishi, A. Thermochim. Acta 2003, 400, 175.

23Kawai, Akiko.; Sugahara, Y.; Park, I. Y.; Kuroda, K.; Kato, C. Ceram. Powder Sci. IV 1991, 22, 75.

${ }^{24}$ Vithal Ghule, A.; Lo, B.; Tzing, S.; Ghule, K.; Chang, H.; Ling, Y. C. Chem. Phys. Lett. 2003, 381, 262.

${ }_{25}^{25}$ Bera, P.; Rajamathi, M.; Hegde, M. S.; Kamath, P. V. Bull. Mater. Sci. 2000, 23, 141

${ }^{26}$ Bae, H. Y.; Choi, G. M. Sens. Actuators, B 1999, 55, 47.

27Manna, L.; Scher, E. C.; Alivisatos, A. P. J. Am. Chem. Soc. 2000, 122, 12700.

28 Jiang, X.; Xie, Y.; Lu, J.; Zhu, L.; He, W.; Qian, Y. Chem. Mater. 2001, 13, 1213.

$\underline{29}$ Yu, S.; Wu, Y.; Yang, J.; Han, Z.; Xie, Y.; Qian, Y.; Liu, X. Chem. Mater. 1998, 10, 2309.

30Morioka, H.; Tagaya, H.; Karasu, M.; Kadokawa, J.; Chiba, K. Inorg. Chem. 1999, 38, 4211.

31Cheary R. W.; Coelho A. A. Programs XFIT and FOURYA, deposited in CCP14. Powder Diffraction Library, Engineering and Physical Sciences

Inorganic Chemistry, Vol 45, No. 9 (April 2006): pg. 3766-3773. DOI. This article is (C) American Chemical Society and permission has been granted for this version to appear in e-Publications@Marquette. American Chemical Society does not grant permission for this article to be further copied/distributed or hosted elsewhere without the express permission from American Chemical Society. 
Research Council, Daresbury Laboratory, Warrington, England. (http://www.ccp14.ac.uk/tutorial/xfit- 95/xfit.htm), 1996.

32] Jenkins, R.; Synder, R. L. Introduction to X-ray Powder Diffractometry; Wiley: New York, 1996.

33 Powder Diffraction File Alphabetical Indexes. Inorganic Phases. JCPDS, International Centre for Diffraction Data: Swartmore, PA, 1999.

34 NIST Spec Data Center, Stein, S. E. dir. IR and Mass Spectra. In NIST Chemistry Webbook, Acetic acid and acetone: Coblentz Society, Inc, http://webbook. nist.gov/chemistry/.

${ }^{35}$ Rajamathi, M.; Thomas, G. S.; Kamath, P. V. Proc. Indian Acad. Sci. (Chem Sci.) 2001, 113, 671.

36Stahlin, W.; Oswald, H. R. Acta Crystallogr. B, 1970, 26, 860.

37 Masciocchi, N.; Corradi, E.; Sironi, A.; Moretti, G.; Minelli, G.; Porta, P. J. Solid State Chem. 1997, 131, 252.

38Kandare, E.; Hossenlopp, J. M. J. Phys. Chem. B. 2005, 109, 8469.

39 Pestman, R.; Koster, R. M.; van Duijne, A.; Pieterse, J. A. Z.; Ponec, V. J. Catal. 1997, 168, 265.

40 Mekhemer, G. A. H.; Halawy, S. A.; Mohamed, M. A.; Zaki, M. I. J. Catal. 2005, 230, 109

41 Davis, R.; Schultz, H. P. J. Org. Chem. 1962, 27, 854.

42Gonzalez, F.; Munuera, G.; Prieto, J. A. J. Chem. Soc, Faraday Trans. 1 1978, 74, 1517.

433Nakai, R.; Sugh, M.; Nakao, H. J. Am. Chem. Soc. 1959, 81, 1003. 44Spitz, R. N.; Barton, J. E.; Barteau, M. A.; Staley, R. H.; Sleight, A. W. J. Phys. Chem. 1986, 90, 4067.

45 Nishizawa H.; Yuasa, K. J. Solid State Chem. 1998, 141, 229.

${ }^{46}$ Pestman, R.; Koster, R. M.; Pieterse, J. A. Z.; Ponec, V. J. Catal. 1997, $168,255$.

7ㅡㄴarnes, W. H.; Pike, R. D.; Cole, J. R.; Doyal, A. S.; Kimlin, E. J.; Lee, J. T.; Murray, P. J.; Quinlan, R. A.; Zhang, J. Polym. Degrad. Stab. 2003, 82, 15

488ike, R. D.; Starnes, W. H.; Jeng, J. P.; Bryant, W. S.; Kourtesis, P.; Adams, C. W.; Bunge, S. D.; Kang, Y. M.; Kim, A. S.; Kim, J. H.; Macko, J. A.; O'Brien, C. P. Macromolecules 1997, 30, 6957.

49$K$ Klenov, D. O.; Kryukova, G. N.; Plyasova, L. M. J. Mater. Chem. 1998, 8, 1665.

\section{Supporting Information}

Inorganic Chemistry, Vol 45, No. 9 (April 2006): pg. 3766-3773. DOI. This article is (C) American Chemical Society and permission has been granted for this version to appear in e-Publications@Marquette. American Chemical Society does not grant permission for this article to be further copied/distributed or hosted elsewhere without the express permission from American Chemical Society. 


\section{Supporting Information For:}

Thermal Degradation of Acetate-Intercalated Hydroxy Double and Layered Hydroxy Salts

Everson Kandare and Jeanne M. Hossenlopp ${ }^{*}$

Department of Chemistry, Marquette University, P. O. Box 1881,

Milwaukee, WI 53201-1881

Table of Contents

S-2 TGA-FTIR Profiles for ZHA in Air

S-3 TGA-FTIR Profiles for ZNA in Air

S-4 TGA-FTIR Profiles for ZCA in Air

*Corresponding author: jeanne.hossenlopp@mu.edu 
TGA-FTIR Profiles for ZHA in Air
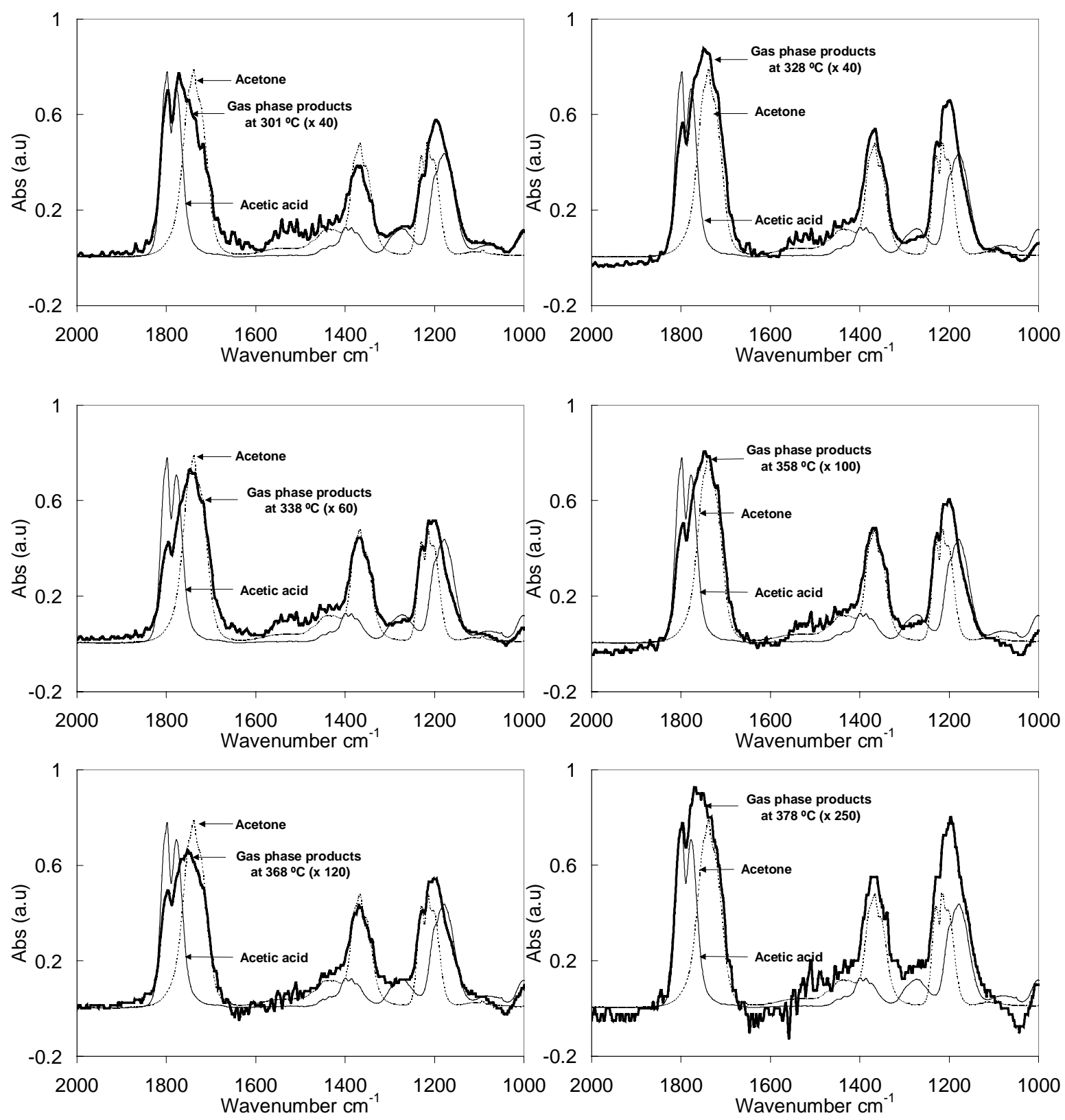
TGA-FTIR Profile of ZNA in Air
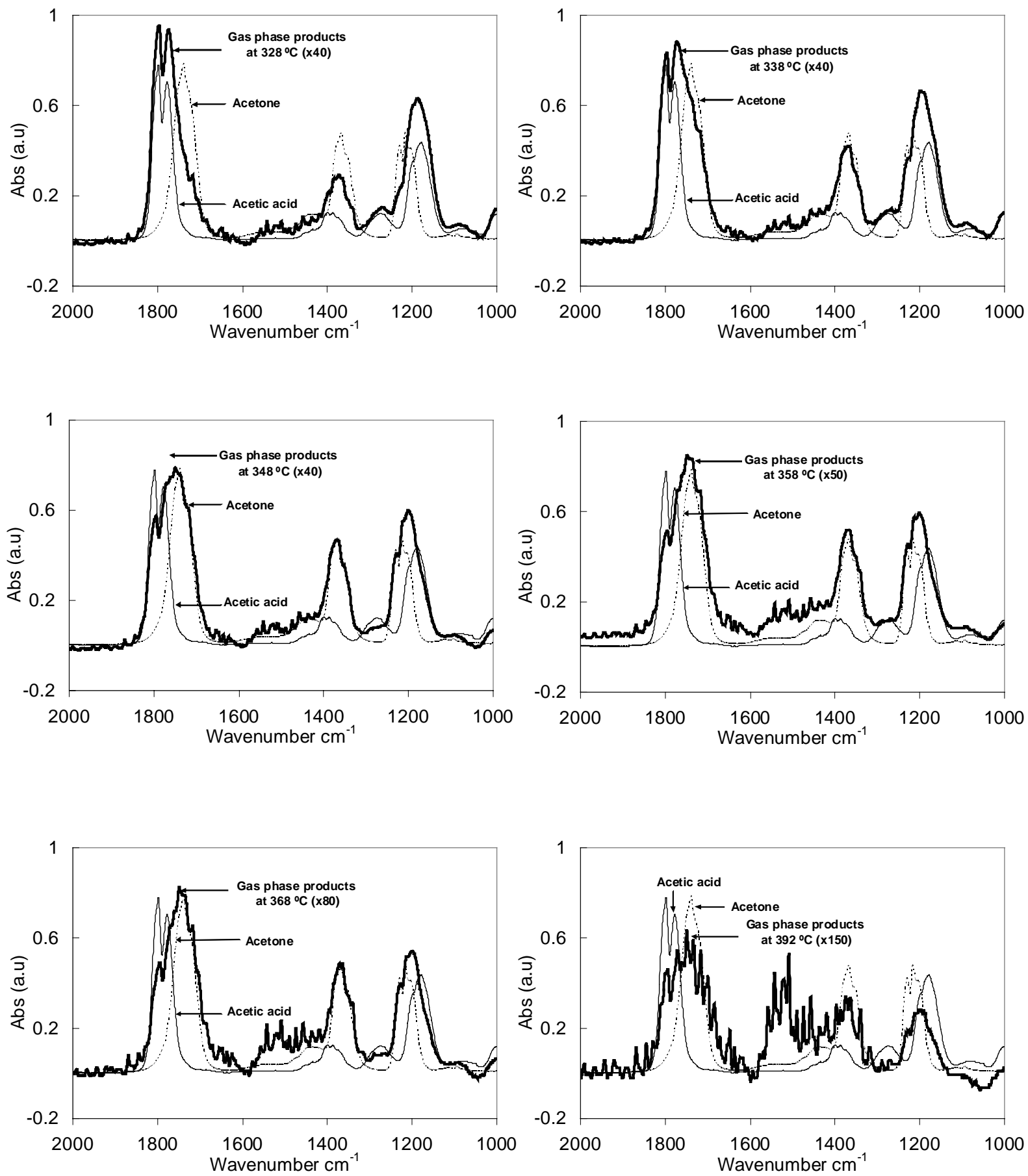
TGA-FTIR Profiles for ZCA in Air
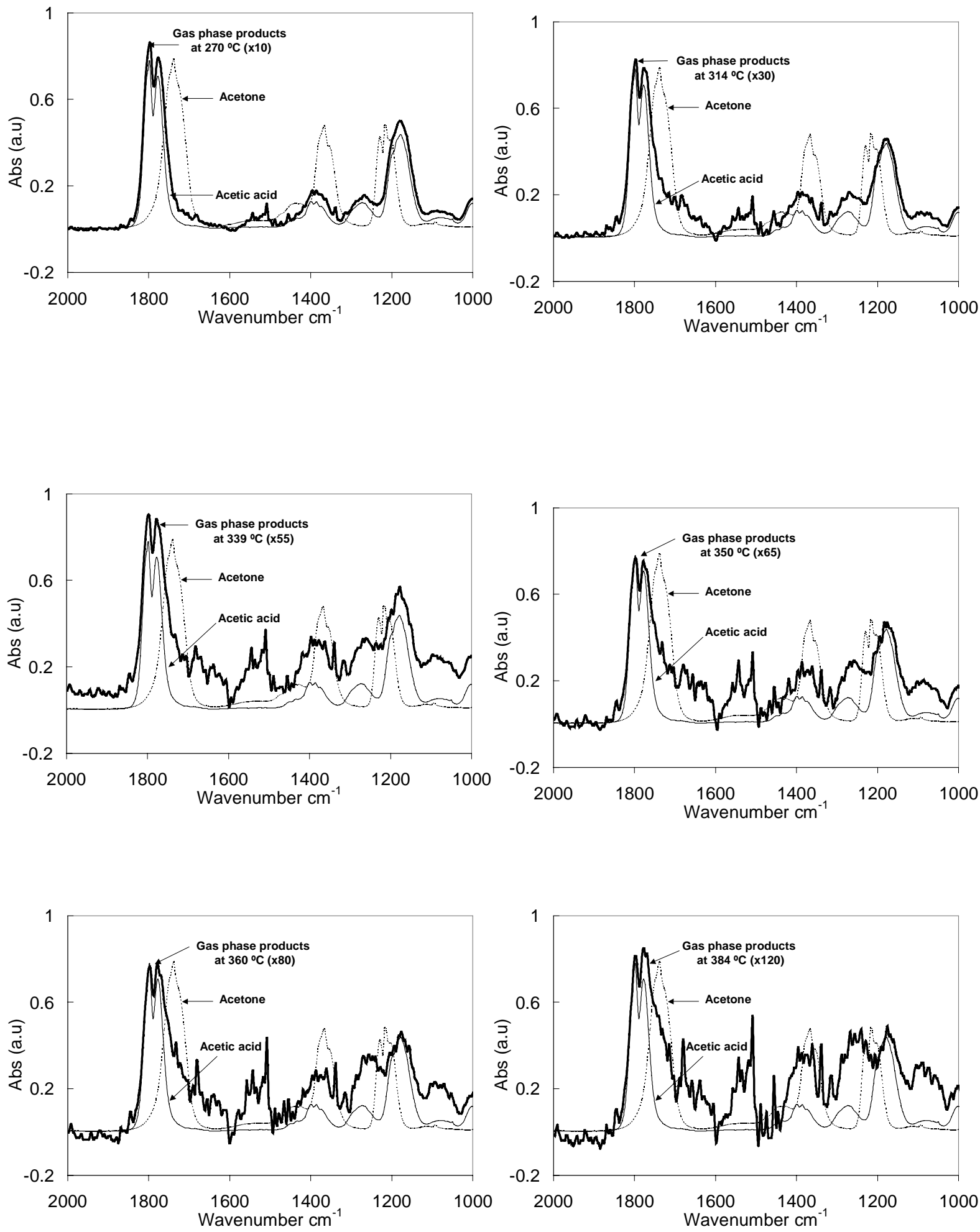